\title{
SHORT MEASURES OF ORGANISATIONAL COMMITMENT, CITIZENSHIP BEHAVIOUR AND OTHER EMPLOYEE ATTITUDES AND BEHAVIOURS: ASSOCIATIONS WITH WELL-BEING ${ }^{1}$
}

\author{
Mohamad Irwan AHMAD ${ }^{2}$ \\ Kirsty FIRMAN ${ }^{3}$ \\ Hugo SMITH $^{4}$ \\ Andrew P SMITH ${ }^{5}$
}

\author{
Received Date (Başvuru Tarihi): 01/11/2018 \\ Accepted Date (Kabul Tarihi): 15/11/2018 \\ Published Date (Yayın Tarihi): 30/11/2018
}

\begin{abstract}
Background:

There is considerable literature on Psychological Contract Fulfilment and other employee attitudes and behaviours. Similarly, there is increasing literature on well-being at work, the well-being process and short measures of psychosocial concepts.

\section{Aims and objectives}

The first aim of the present study was to develop short measures of employee attitudes and behaviours and validate these by examining associations with longer established measures. The second aim was to examine associations of these short measures with Psychological Contract Fulfilment and aspects of well-being.

\section{Methods}

The study involved an online survey of 166 workers from the USA recruited using Mechanical Turk and delivered using Qualtrics software. The survey included established measures and the newly developed short items.

Results

There were high correlations between short items and established measures. The short items were associated with Psychological Contract Fulfilment and the well-being variables in the predicted direction.

Conclusion

The new short items can be used in future multi-variate analyses of the well-being of workers. This will lead to an increase in our knowledge and the development of new models that can be of theoretical and practical significance.

Keywords: Wellbeing; Psychological Contract Fulfilment; Organisational Commitment; Citizenship Behaviour; Intention to Quit; Job Security; Work Effort; Work Life Balance.
\end{abstract}

\footnotetext{
${ }^{1}$ This article was presented in "Business and Organization Research Conference-BOR 2018"

${ }^{2}$ Centre for Occupational and Health Psychology, School of Psychology, Cardiff University, (deceased)

${ }^{3}$ Centre for Occupational and Health Psychology, School of Psychology, Cardiff University, https://orcid.org/0000-0002-2658-1435

${ }^{4}$ Centre for Occupational and Health Psychology, School of Psychology, Cardiff University, https://orcid.org/0000-0002-1276-6738

${ }^{5}$ Prof., Centre for Occupational and Health Psychology, School of Psychology, Cardiff University, smithap@ cardiff.ac.uk https://orcid.org/0000-0001$\underline{8805-8028}$
} 


\section{ÖRGÜTSEL BAĞLILIK, ÖRGÜTSEL VATANDAŞLIK DAVRANIŞI VE DİĞER ÇALIŞAN TUTUMLARI VE DAVRANIŞLARININ KISA ÖLÇÜMLERİ: IYYI OLUŞ İLE İLİSKIILENDİRME}

ÖZ

\section{Literatür Taraması}

Psikolojik Sözleşmenin Gerçekleştirilmesi ve çalışanların diğer tutum ve davranışlarına yönelik hakkinda önemli bir literatür bulunmaktadır. Benzer şekilde işyerinde refah, refah süreci ve psikososyal kavramların kısa ölçütleri hakkinda da var olan literatür giderek genişlemektedir.

\section{Amaç ve hedefler}

Bu çalışmanın ilk amacı, çalışanların tutum ve davranışlarına yönelik kısa ifadeler ve önlemler geliş̧tirmek ve bunları daha uzun vadeli önlemlerle olan ilişskilerini inceleyerek onaylamaktır. İkinci amaç, bu klsa önlemlerin Psikolojik Sözleşme Yerine Getirilmesi ve iyi oluş durumuyla ilişskilerini incelemek yönündedir.

\section{Yöntemler}

Çalışma, Mekanik Turk kullanılarak işe alınan ve Qualtrics yazılımı kullanılarak teslim edilen ABD'den 166 iş̧̧inin çevrimiçi bir anketini içermektedir. Anket, var olan önlemleri ve yeni geliştirilen kısa ifadeleri içermektedir.

\section{Sonuçlar}

Kısa ifadeler ve hâlihazırda var olan ifadeler arasında yüksek korelasyonlar bulunmaktadır. Kısa ifadeler, Psikolojik Sözleşmenin Gerçekleştirilmesi ve iyi oluş değiş̧kenlerinin beklenen yönde gerçekleşmesi ile iliş̧kilendirilmiştir.

\section{Sonuç}

Yeni kısa ifadeler, çalışanların refahının gelecekteki çok değişkenli analizlerinde kullanılabilir. Bu, konuya dair bilginin ve farkindalığın artmasina ve teorik ve pratik anlamdaki yeni modellerin gelişstirilmesine yol açacaktır.

Anahtar Kelimeler: Iyy oluş; Psikolojik Sözleşmenin Gerçekleştirilmesi; Örgütsel Bağlllık; Örgütsel Vatandaşllk Davranışı; İşten Ayrllma Çıkma Niyeti; İş Güvenliği; İşe Dair Çaba; İş Yaşam Dengesi

\section{INTRODUCTION}

Today, organisations have developed and changed drastically to fulfil the needs of the globalisation era. These developments include changes in the economy, technology, innovation and organisational restructuring and these have been the main factors influencing the labour market, organisations, nature of jobs and work activity (Isaksson et al., 2003). These changes seem to contribute to the changes of employee management and need serious attention because, if not controlled carefully, they can contribute to various problems as employees are an important element who act as the backbone of an organisation ( $\mathrm{Ng}$ et al., 2012).

In this context, the Psychological Contract is seen as playing an important role in explaining changes in relationships between employees and their organisation (Rousseau, 1995; Guest and Conway, 2002; Dabos and Rousseau, 2004). The Psychological Contract is the exchange relationship between the organisation and employee where the employee offers an obligation to the organisation and the organisation in return will appreciate this obligation with some terms and agreement (Rousseau, 1989). This means the employee will deliver what is necessary on condition that they receive rewards equitable with the effort being put in. The Psychological Contract is also an unwritten agreement regarding the relationship between employer and employee and is different from work contracts that are often formally written down. When changes in the nature of work occur, employees need to reorganise their Psychological Contract so that it is in line with the requirements of change for 
the benefit of the organisation and the employee. If this reorganisation fails, the employee may exhibit resenting behaviour (Rousseau, 2011).

This situation is known as 'Psychological Contract Breach' which happens when employees feel that the organisation no longer supports their well-being but instead is merely safeguarding the interests and well-being of the organisation. The employee might not have been given ample training to face change but may be forced to give their best without rewards that are commensurate with the difficulties caused by the change. As a result, their well-being at work is disturbed and eventually could lead to various performance-related effects such as low work performance (Marks, 2001; Millward and Hopkins, 1998), low engagement (Bal et al., 2003) and weak organisational citizenship behaviour (Zhao et al., 2007; Lee and Allen, 2002; Turnley, 2003). Finally, both parties may suffer negative consequences where the organisation could no longer operate effectively and employees no longer have an interest in their work.

The Psychological Contract is an implicit understanding between employee and employer (Argyris, 1960) and is a relationship that has been developed throughout the career processes where employees have higher productivity and lower grievances in return for acceptable wages and job security (Taylor and Tekleab, 2004). Rousseau (1989) also described the Psychological Contract as an individual's beliefs concerning the mutual obligations that exist between the individual and their employer. The Psychological Contract has long been identified in the field of human resource management as well as industrial and organisational psychology. Rousseau (1989) was responsible for bringing the concept of the Psychological Contract to the attention of others and this has greatly influenced contemporary research.

The development of the Psychological Contract began with the seminal works of Argyris (1960), Levinson et al. (1962) and Schein (1965). Two other theories namely social exchange theory developed by Blau (1964) and Gouldner (1960) have also been as a significant as theories based on the Psychological Contract. Research on the Psychological Contract has been extremely important because it can influence many factors related to performance (Rousseau, 1989; Coyle-Shapiro and Parzefall, 2008). In a business world with lots of ambiguity, adjustment and anxiety, it has become more important than ever to ensure the healthy and progressive relationship between employers and their employees.

When a breach of the Psychological Contract occurs, employees may exhibit negative emotional stress like anger, disappointment and betrayal and, finally, they may cease to work efficiently and may intend to quit the organisation (Robinson et al., 1994). The model proposed by Guest (1989) shows the attitudinal and behavioural effects related to changes in the Psychological Contract (see Figure 1). 


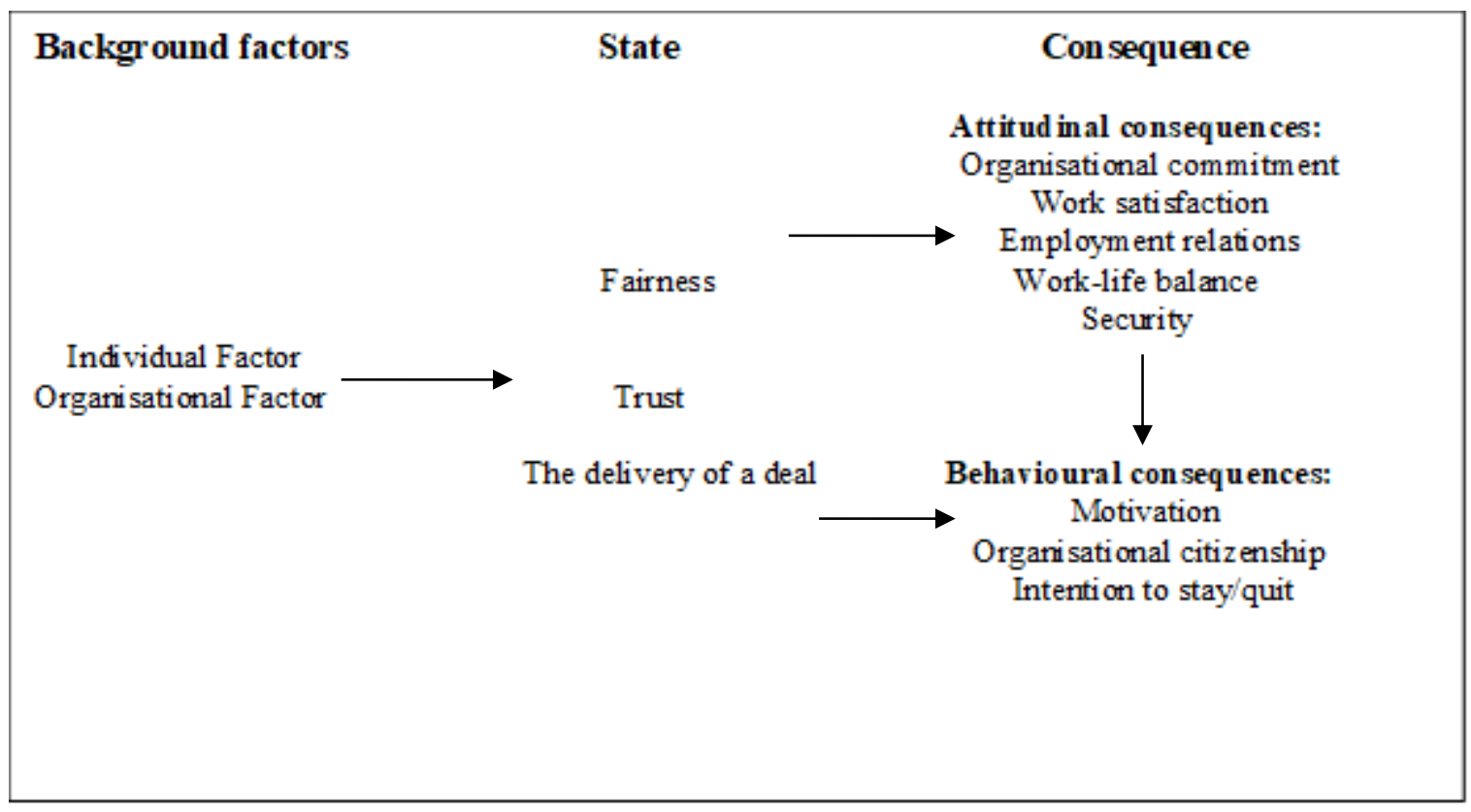

Figure 1. A Framework For The State Of The Psychological Contract (Guest, 1989)

The present study aimed to integrate all models and theories discussed earlier in an effort to provide an understanding of the meaning of the phenomena in a comprehensive manner based on the variables stated in the models. Sonnentag and Frese (2013) suggested that results will be richer and able to explain the related phenomenon effectively and comprehensively if many of the factors are studied simultaneously. Psychological Contract Fulfilment is now a popular construct because it can influence many aspects of work performance factors and wellbeing. However, the research is still ongoing due to many gaps in our knowledge. For example, there is a lack of research integrating different theoretical perspectives. Most of the research on the Psychological Contract has used social exchange theory and very little research attempts to integrate Psychological Contract Fulfilment with other theories. In addition, there is little research examining key antecedents and consequences of the Psychological Contract in the same study. There is also a lack of research examining the effect of the Psychological Contract on well-being. Most of the research on Psychological Contract Fulfilment has explored the attitudes and behavioural outcomes, but very little has looked at the well-being of employees.

De Cuyper and De Witte (2006) compared the well-being of permanent and temporary staff. Psychological Contract theory assumes (1) that job insecurity effects are due to a violation of the relational Psychological Contract, and (2) that permanent staff engage more in relational Psychological Contracting than temporary staff. This suggests that job insecurity is expected to be more problematic in terms of outcomes for permanent staff than temporary staff. The results supported these hypotheses. De Cuyper, Van der Heijden and De Witte (2011) investigated interactions between perceived employability and employees' perceptions about Psychological Contract obligations made by the 
employer in relation to life and job satisfaction, self-rated performance, and turnover intention. It was hypothesized that perceived employability would relate positively to job satisfaction, life satisfaction, and self-rated performance and negatively to turnover intention under the condition of few promises by the employer. Perceived employability was positively related to all outcomes except job satisfaction. The number of promises was positively related to job and life satisfaction, and to selfrated performance, and negatively to turnover intention. The relationships between perceived employability and the outcomes were relatively stronger and positive under the condition of few promises compared with many promises.

In the present study fairness, trust and delivery of deals was measured using The Psychological Contract Fulfilment Scale developed by Guest and Conway (2002). The measurement assessed the extent to which the respondent felt the organisation had kept its promises ( 7 items), treated them fairly ( 2 items) and how much they trusted the organisation (4 items). Sample items include "Has the organisation fulfilled its promise or commitment to.... provide you with a reasonably secure job", "Overall, do you feel you are fairly rewarded for the amount of effort you put into your job." and "To what extent do you trust your immediate manager to look after your best interests."

The main focus of the study was on the attitudinal and behavioural consequences of Psychological Contract Fulfilment. A key variable was organisational commitment. Organisational commitment is a set of employee's attitudes and behaviours that can help the organisation to achieve its goals and at the same time, maintain the strong desire in the employee to stay as a member of the organisation (Steers, 1977). Similarly, Mowday et al. (1984) proposed the same definition as mentioned by Steers (1997) that organisational commitment is actually a stronger trust embedded among employees on organisational goals and values, readiness to provide an effort and the strong desire to stay as a member in an organisation. However, in defining organisational commitment, Meyer and Allen (1991) have described it comprehensively when they stated that organisational commitment is a psychological state that binds an employee with his or her organisation and can be categorised based on three components, namely an affective commitment, continuance commitment and normative commitment.

There has been some previous research on organisational commitment and well-being. Siu (2002) found that in a sample of Chinese workers organisational commitment and well-being were positively related. Similarly, Coetzee and Rothmann (2005) found that organisational commitment moderated the effect of occupational stress on ill-health. Research by Nikolaou and Tsaousis (2002) also linked organisational commitment to a positive characteristic namely emotional intelligence. Panaccio and Vandenberghe (2009) examined the contribution of perceived organizational support and four categories of organizational commitment (affective, normative, perceived sacrifice associated 
with leaving and perceived lack of alternatives) to employee psychological well-being. Affective organizational commitment mediated a positive relationship between perceived organizational support and well-being. In addition, perceived organizational support was negatively related to perceived lack of employment alternatives which, in turn, was negatively related to well-being. Normative commitment and perceived sacrifice associated with leaving were unrelated to well-being.

Another key variable in this research was work-life balance (WLB). Work-life balance can be defined as the absence of conflict between work and personal/family matter (Frone, 2003; Frone et al., 1992; Quick et al., 2004). This concept can also be known as work-family balance and most of the previous research has used this term interchangeably (Reiter, 2007). In further defining this, it seems to be hard for employees to diminish conflict in totality, but they can minimise the degree of conflict by balancing emotional, behavioural and time demands of paid work, family and personal duties simultaneously (Hill et al., 2001). There is extensive research showing that work-life balance influences well-being (Feigon et al., 2018; Haar et al., 2014; Yu, Manku \& Backman, 2018). Some research treats work-life balance as an outcome whereas other studies see it as a predictor of wellbeing outcomes (e.g. Siu, 2013; Bell et al., 2012) or as both an outcome of job characteristics and predictor of health (Kinman and Jones, 2008). Other research suggests more complex relationships between work-life balance and work outcomes. For example, Haider, Jabeen and Ahmad (2018) found that psychological wellbeing mediates the link between work-life balance and job performance, and employees' satisfaction with coworkers enhances job performance by strengthening the effect of worklife balance on psychological wellbeing. Recovery from work may also be a key variable in having a good WLB (Demeroutiet al., 2013) although other researchers suggest that resource allocation is the key variable (Grawitch et al., 2010) whereas others emphasise need fulfilment (Gropel and Kuhl, 2009).

Job security was also included in the present study. Job security can be defined as a state where the individual feels secured in their current job. This definition can be supported by the definition used by Dasgupta (2001: 2) when he described job security as "the absence of fear of employment threat and loss". On the other hand, "job security means that workers have protection against arbitrary and short notice dismissal from employment, as well as having a long-term contract of employment and having employment relations that avoid casualization" (ILO, 1995). This state of security will contribute to positive psychological aspects such as a reduction of anxiety, prevention of mental strain and avoidance of any ambiguities among employees. Again, there is an extensive literature confirming the associations between job security and well-being (De Witte, 1999; De Witte et al., 2016; Schaufeli, 2016). Research has examined the antecedents of job insecurity, the negative consequences of it, and variables that may buffer the job insecurity-outcomes relationship (De Witte et al., 2015; Silla et al., 
2009; Stiglbauer et al., 2012). Other research has found that job insecurity mediates the relationship between employability and employees' well-being (De Cuyper et al., 2008). The relationship between job insecurity and psychological outcomes is more negative among permanent compared with temporary workers (De Cuyper and De Witte, 2007). Job satisfaction, another attitudinal consequence of Psychological Contract Fulfilment, was also included in the present survey. This concept also plays a key role in models of well-being at work (see next section on the Demands-Resources-Individual Effects model).

The behavioural consequences of Psychological Contract Fulfilment included motivation/effort, organisational citizenship and intention to quit. Motivation is a state of needs or a desire for something that makes an individual work towards the goal (Reeve, 2009). Guay et al. (2010) described motivation as the reason underlying individual's behaviour. Without the sense of motivation, individuals would achieve nothing in their life. On the other hand, motivation can also be understood as "the attributes that move us to do or not to do something" (Gottfried et al., 2004). Motivation can be divided into two types, namely intrinsic and extrinsic motivation (Deci et al., 1999). Intrinsic motivation is when an individual is doing some actions because of their inner desire, and it is different from extrinsic motivation, which needs external factors such as rewards and high wages to drive the person's motivation. Motivational processes play a pivotal multifunctional role in adaptation to the workplace and reaction to stress (Fernet and Austin, 2014). Changes in motivation are also associated with changes in well-being at work (Bjorklund et al., 2013). Other variables such as organisational identication will combine with motivation to influence wellbeing (Wegge et al., 2006).

Work effort can be defined as the amount of energy employees put in to work successfully (Ilgen and Klein, 1989). Work effort is different from motivation and there is always some confusion between both of these definitions. In this case, motivation comes first and is the psychological state that pushes the employees to make an effort of any required behaviours (Bandura and Cervone, 1986; Patche, 1970; Naylor et al., 1980). Motivation is a psychological state and effort is a physical state and both of them are related. Both play key roles in psychological theories of stress and well-being (e.g. Effort-Reward Imbalance - Siegrist, 1996). A work-effort recovery mechanism has also been shown to play a crucial role in the associations between sleep quality, adverse work conditions, rumination, after-work fatigue and well-being (Kompier et al., 2012).

Another behavioural consequence of Psychological Contract Fulfilment included in the present study was organizational citizenship behaviour (OCB). OCB can be defined as an individual's desire to do extra-work related behaviour beyond the actual tasks and duties prescribed in their job description or measured in formal evaluations (Bateman and Organ, 1983). This includes cooperation with peers, performing extra duties without complaint, punctuality, volunteering and helping others, using time 
effectively, conserving resources, sharing ideas and positively representing their organisation (Turnipseed and Rasulli, 2005). These behaviours are positive volunteering, therefore, the employee cannot be penalised if they do not show the behaviour. However, the employee can be educated on these aspects using an appropriate intervention such as training (Organ, 1988).

Organisational Citizenship Behaviour has 5-dimensions, namely altruism, conscientiousness, courtesy, civic virtue, and sportsmanship:

a) Altruism

Altruism can be defined as helping or helpfulness (Organ, 1997). Employees who have high altruism tend to help the people inside of an organisation by voluntarily helping new employees, helping coworkers who are overloaded and assisting when workers are absent (Tambe and Shanker, 2014). This type of behaviour is important because employees must work cooperatively if they are to influence the future of the organisation. This supports the statement by Podsakoff et al. (2000), suggesting that altruism is positively correlated with high performance at work.

b) Conscientiousness

Conscientiousness is referred to as discretionary behaviour that goes beyond the minimum roles at work such as working hard, not taking extra breaks, and obeying the rules and regulations of the organisations (Podsakoff et al., 1990). Employees with high conscientiousness are likely to avoid absenteeism, be punctual, have a penchant towards conserving resources and be responsible members of the organisation, organised, self-disciplined, hard -working and accountable (Borman et al., 2001; Tambe and Shanker, 2014).

c) Courtesy

Courtesy refers to the employee's behaviours and gestures that help others with any interpersonal and work-related problems (Organ, 1990b). An employee with this kind of OCB is likely to avoid conflict due to confronting another employer and to avoid a crisis at work by taking early actions (Podsakoff et al., 2000). For example, courteous behaviour might involve informing co-workers about the cancelled meeting before they arrive at the meeting room.

d) Civic virtue

Civic virtue refers to the employee's constructive involvement in the organisational political process (Tambe and Shanker, 2014). The employee may be actively involved through expressing significant opinions about organisational development and enhancement, attending meetings, discussing potential future prospects and reading all the organisation communications such as memos, emails and the internal newsletter (Podsakoff et al., 1990).

e) Sportsmanship 
Sportsmanship is referred to as "a willingness to tolerate the inevitable inconveniences and impositions of work without complaining." (Organ, 1990). The employee with high sportsmanship tends to avoid complaining about drastic changes or difficulties at work and tolerates these with a positive attitude.

There has been previous research on OCB and well-being. For example, Boyd and Nowell (2017) investigated the predictive power of a sense of community responsibility (SOC-R) and a sense of community (SOC). SOC was a better predictor of employee well-being, while SOC-R more strongly predicted organizational citizenship behaviour. Davila and Finkelstein (2013) examined the relationship between OCB and well-being. Both organizational citizenship behaviour and its motives were associated with well-being, with altruistic motives showing a stronger correlation than egoistic motives. Other research has examined the importance of the target of OCB (Kumar et al., 2016). OCB targeted at other individuals was found to be positively related with relatedness need satisfaction and OCB towards the organisation was positively related with psychological health.

The present research tests the relationship between dimensions of OCB and measures of wellbeing. The study hypothesizes that OCB will be related positively with psychological health and negatively with burnout. OCB targeted at other individuals (OCBI) will positively relate with relatedness need satisfaction. It further hypothesizes a negative relationship of relatedness need satisfaction with burnout and burnout with psychological health. A web-based survey was used for data collection for the study. OCBI was positively related with relatedness need satisfaction and OCBOrganization was positively related with psychological health. Further, relatedness need satisfaction was negatively associated with burnout and burnout was negatively associated with psychological health. Other research has compared the different components of OCB on well-being. Yurcu, Çolakoğlu and Atay (2015) found that three dimensions of organizational citizenship behavior, altruism, sportsmanship and civic virtue, had a significant positive effect, whereas the conscientiousness dimension had a negative effect on employees' subjective well-being.

The final measure of the behavioural consequences of Psychological Contract Fulfilment was intention to quit. Intention to quit can be defined as an employee's plan to move out or to quit from the current membership of an organisation and to search for another job in the near future (Weisberg, 1994). Since quitting from an organisation is a big issue in an employee's life, he or she must consider many factors as their work has provided them with economic funds. Usually, they will quit from the current organisation if they were shocked with the organisation's system such as merging or downsizing and the decision frames that are not meeting the current expectation (Greenberg, 2011). Alternatively, their job may represent a temporary stage of their career path. Negative job characteristics are usually related to a stronger intention to quit (Saucan et al., 2014; Grebner et al., 
2003) whereas organizational values supportive of better WLB are associated with lower intention to quit scores (Burke et al., 2003).

The aim of the present study was to combine the various components of the Psychological Contract with a model of well-being at work. The model used here was the Demands-ResourcesIndividual Effects (DRIVE) model (Mark and Smith, 2008). This model was initially developed to examine the stress process. Mark and Smith (2008) suggest that it is desirable to have a model of the stress process that includes negative and positive job characteristics, individual experiences, and subjective appraisals of perceived stress and job satisfaction. Their model included factors from the Demands-Control-Support model (DCS model; Johnson and Hall, 1988), the Effort-RewardImbalance model (ERI model; Siegrist, 1996), coping behaviours (Folkman and Lazarus, 1980), and attributional explanatory styles (Peterson, 1991). The outcomes included anxiety, depression, and job satisfaction. The variables were categorised as work demands, work resources (e.g. control, support), individual differences (e.g. coping style, attributional style), and outcomes. The model was intended as a framework into which any relevant variables could be included and in the present study the novel variables were those related to the Psychological Contract.

It is not possible to measure every possibly important variable (Smith et al., 2009) and variables were chosen to assess the broad range of variables associated with well-being while also balancing this with a realistic selection of the vast number of variables and measures that have been developed in this area. The variables that were chosen represented a multi-faceted approach to workplace well-being used in previous studies (e.g. Mark and Smith, 2012a; 2012b; Smith et al., 2004; Smith et al., 2000). The measures were congruent with international and national well-being definitions (Waldron, 2010; Wismar et al., 2013), had strong evidence for their association with well-being (e.g. Diener, et al., 1999; DeNeve and Cooper, 1998; Diener, et al., 2003; Tsutsumi and Kawakami, 2004; Van Der Doef and Maes, 1999) and were recommended for well-being assessment (e.g. Rick et al., 2001; Parkinson, 2007).

The inclusion of additional variables can improve predictive validity of the multi-dimensional nature of well-being but increases the potential for increased redundancy. While these variables have each been associated with well-being, it is unclear whether they have independent relationships or act through associations with other variables. For example, optimism may be associated with well-being through coping or explanatory style, with optimists being more likely to use problem focused coping rather than emotional coping, and having internal attributions for positive events (Kluemper et al., 2009; Scheier et al., 1994). Self-esteem may also involve a positive expectation regarding one's selfworth (Scheier et al., 1994) and both concepts may reflect broader personality traits such as extraversion and neuroticism (Sharpe et al., 2011; Scheier et al., 1994) and therefore including all of 
these variables may be unnecessary. However, such variables may account for a significant amount of unique variance (Scheier et al., 1994) and it is not fully established whether they have unique associations beyond those accounted for by broad personality characteristics (Diener et al., 2003) or whether some measures may be assessing the same variance in outcomes (Judge et al., 2002). Similarly, outcome variables such as satisfaction with life, anxiety/depression and negative affect have been shown to be correlated at levels between .31 and .72, but it has also been suggested that they have some degree of unique variance (Pavot and Diener, 1993). Although there is some potential for redundancy in the components of well-being models it is unclear which the relevant variables are.

The Well-being Process Questionnaire (WPQ; Williams and Smith, 2012; Williams, 2015) was developed by using short measures that were highly correlated with longer validated scales. The newly developed single-item measures were based on guidance about uni-dimensionality and clarity for the respondent (Sackett and Larson, 1990). The single-item measures included an initial statement or question and were followed by examples of what the item was referring to. These examples were statements taken from the multi-item measure. An example (optimism) is shown below:

"In general, I feel optimistic about the future (For example: I usually expect the best, I expect more good things to happen to me than bad, it is easy for me to relax) Disagree strongly 123456789 10 Agree strongly". Each question either had a response scale ranging from "Disagree strongly" to "Agree strongly" (rated on a scale of 1 to 10), while those with an initial question (e.g. "On a scale of one to ten, how depressed would you say you are in general?") had the response scale from "Not at all" to "Extremely" with a response scale from 1-10 which was chosen for practical and statistical reasons. A consistent simple scale makes responding easier and a 1-10 scale allows a greater range of potential responses than shorter Likert scales. Reliability has been shown to increase with the number of alternatives and this benefit is most applicable to questionnaires using short items (Maydeu-Olivares et al., 2009). These short measures were shown to be highly correlated with the longer scales, and the correlation was often greater than the correlations between single items and scale totals from the established measures. The single items were also shown to have the same predictive validity as the longer versions and had a good test-re-test reliability (Williams et al., 2017; Williams and Smith, 2018a, b, c.; Williams et al., 2017; Williams et al., 2017).

\section{AIMS AND OBJECTIVES}

The present research aimed to investigate and explore the antecedents and outcomes of the Psychological Contract Fulfilment among employees by using a combination of the Guest model and the DRIVE model. There were three main research objectives:

i. To examine whether single-item measures can accurately (validity and reliability) become a measure of the antecedents and outcomes of Psychological Contract Fulfilment. 
iii. To identify the relationship between work demands, work resources, individual differences, and personality with Psychological Contract Fulfilment.

iv. To identify the relationship between work demands, work resources, individual differences, personality, and Psychological Contract Fulfilment with work attitudes, work behaviours and wellbeing.

\section{METHOD}

This study was carried out with the approval of the Ethics Committee, School of Psychology, Cardiff University, and the informed consent of the volunteers.

\subsection{Participants}

The participants were 166 workers from the USA recruited using Mechanical Turk. Details of their demographics and job characteristics are shown in Table 1.

Table 1. Respondents' Demographic and Occupational Profile

\begin{tabular}{|c|c|c|c|}
\hline Variable & Response Category & Frequency & Percentage $(\%)$ \\
\hline Age & $\begin{array}{l}20-30 \text { years } \\
31-40 \text { years } \\
41-50 \text { years } \\
51-60 \text { years } \\
61-70 \text { years }\end{array}$ & $\begin{array}{l}54 \\
68 \\
21 \\
11 \\
12\end{array}$ & $\begin{array}{c}32.5 \\
41.0 \\
12.7 \\
6.6 \\
7.2\end{array}$ \\
\hline Sex & $\begin{array}{c}\text { Male } \\
\text { Female }\end{array}$ & $\begin{array}{l}96 \\
70\end{array}$ & $\begin{array}{l}57.8 \\
42.2\end{array}$ \\
\hline Marital status & $\begin{array}{c}\text { Single } \\
\text { Living with partner } \\
\text { Married } \\
\text { Separated } \\
\text { Divorced } \\
\text { Widowed }\end{array}$ & $\begin{array}{c}59 \\
29 \\
67 \\
3 \\
7 \\
1\end{array}$ & $\begin{array}{c}35.5 \\
17.5 \\
40.4 \\
1.8 \\
4.3 \\
0.6\end{array}$ \\
\hline Education & $\begin{array}{c}\text { Undergraduate Degree } \\
\text { Post-Graduate Degree } \\
\text { Doctorate }(\mathrm{PhD}) \\
\text { Other } \\
\end{array}$ & $\begin{array}{c}108 \\
51 \\
4 \\
3 \\
\end{array}$ & $\begin{array}{c}65.1 \\
30.7 \\
2.4 \\
1.8 \\
\end{array}$ \\
\hline Race & $\begin{array}{c}\text { White } \\
\text { Black Caribbean } \\
\text { Black African } \\
\text { Black neither Caribbean or African } \\
\text { Indian } \\
\text { Chinese } \\
\text { Other }\end{array}$ & $\begin{array}{c}135 \\
4 \\
10 \\
5 \\
3 \\
4 \\
5\end{array}$ & $\begin{array}{l}81.3 \\
2.4 \\
6.0 \\
3.0 \\
1.8 \\
2.4 \\
3.0\end{array}$ \\
\hline Work sector & $\begin{array}{l}\text { Public } \\
\text { Private }\end{array}$ & $\begin{array}{l}68 \\
98\end{array}$ & $\begin{array}{l}41.0 \\
59.0\end{array}$ \\
\hline Yearly income (f) & $\begin{array}{c}<10000 \\
10001-20000 \\
20001-30000 \\
30001-40000 \\
40001-50000 \\
50001-60000 \\
60001>\end{array}$ & $\begin{array}{c}3 \\
13 \\
28 \\
38 \\
24 \\
23 \\
37\end{array}$ & $\begin{array}{c}1.8 \\
7.8 \\
16.9 \\
22.9 \\
14.5 \\
13.9 \\
22.3\end{array}$ \\
\hline Sick leave & $\begin{array}{c}\text { None } \\
1-5 \text { days } \\
6-10 \text { days } \\
11-15 \text { days } \\
>15 \text { days }\end{array}$ & $\begin{array}{c}51 \\
96 \\
14 \\
2 \\
3\end{array}$ & $\begin{array}{l}30.7 \\
57.8 \\
8.4 \\
1.2 \\
1.8\end{array}$ \\
\hline Illness & $\begin{array}{l}\text { Yes } \\
\text { No }\end{array}$ & $\begin{array}{c}29 \\
137\end{array}$ & $\begin{array}{l}17.5 \\
82.5\end{array}$ \\
\hline General health & $\begin{array}{c}\text { Very good } \\
\text { Good } \\
\text { Fair } \\
\text { Bad } \\
\text { Very bad }\end{array}$ & $\begin{array}{c}36 \\
97 \\
28 \\
5 \\
0\end{array}$ & $\begin{array}{c}21.7 \\
58.4 \\
16.9 \\
9.04 \\
0.0 \\
\end{array}$ \\
\hline Work at night & $\begin{array}{c}\text { Never/almost never } \\
\text { Seldom }\end{array}$ & $\begin{array}{l}70 \\
39\end{array}$ & $\begin{array}{l}42.2 \\
23.5\end{array}$ \\
\hline
\end{tabular}




\begin{tabular}{|c|c|c|c|}
\hline & $\begin{array}{c}\text { Sometimes } \\
\text { Often }\end{array}$ & $\begin{array}{l}41 \\
16 \\
\end{array}$ & $\begin{array}{r}24.7 \\
9.6\end{array}$ \\
\hline Work shift & $\begin{array}{c}\text { Never/almost never } \\
\text { Seldom } \\
\text { Sometimes } \\
\text { Often }\end{array}$ & $\begin{array}{l}104 \\
13 \\
26 \\
23\end{array}$ & $\begin{array}{c}62.7 \\
7.8 \\
15.7 \\
13.9\end{array}$ \\
\hline Work long or unsociable hours & $\begin{array}{c}\text { Never/almost never } \\
\text { Seldom } \\
\text { Sometimes } \\
\text { Often } \\
\end{array}$ & $\begin{array}{l}66 \\
42 \\
46 \\
12 \\
\end{array}$ & $\begin{array}{c}39.8 \\
25.3 \\
27.7 \\
7.2 \\
\end{array}$ \\
\hline "On call" work & $\begin{array}{c}\text { Never/almost never } \\
\text { Seldom } \\
\text { Sometimes } \\
\text { Often } \\
\end{array}$ & $\begin{array}{c}89 \\
36 \\
32 \\
9 \\
\end{array}$ & $\begin{array}{c}53.6 \\
21.7 \\
19.3 \\
5.4 \\
\end{array}$ \\
\hline Unpredictable working hours & $\begin{array}{c}\text { Never/almost never } \\
\text { Seldom } \\
\text { Sometimes } \\
\text { Often } \\
\end{array}$ & $\begin{array}{l}74 \\
53 \\
25 \\
14 \\
\end{array}$ & $\begin{array}{c}44.6 \\
31.9 \\
15.1 \\
8.4 \\
\end{array}$ \\
\hline Work harmful exposure & $\begin{array}{c}\text { Never/almost never } \\
\text { Seldom } \\
\text { Sometimes } \\
\text { Often }\end{array}$ & $\begin{array}{c}122 \\
20 \\
17 \\
7\end{array}$ & $\begin{array}{c}73.5 \\
12.0 \\
10.2 \\
4.2\end{array}$ \\
\hline $\begin{array}{l}\text { Handle or touch harmful substances } \\
\text { or materials }\end{array}$ & $\begin{array}{c}\text { Never/almost never } \\
\text { Seldom } \\
\text { Sometimes } \\
\text { Often }\end{array}$ & $\begin{array}{c}122 \\
25 \\
15 \\
4 \\
\end{array}$ & $\begin{array}{c}73.5 \\
15.1 \\
9.0 \\
2.4\end{array}$ \\
\hline $\begin{array}{l}\text { Work task that leave with ringing or } \\
\text { temporary feeling of deafness }\end{array}$ & $\begin{array}{c}\text { Never/almost never } \\
\text { Seldom } \\
\text { Sometimes } \\
\text { Often } \\
\end{array}$ & $\begin{array}{c}138 \\
17 \\
8 \\
3 \\
\end{array}$ & $\begin{array}{c}83.1 \\
10.2 \\
4.8 \\
1.8 \\
\end{array}$ \\
\hline Noise disturbs work environment & $\begin{array}{c}\text { Never/almost never } \\
\text { Seldom } \\
\text { Sometimes } \\
\text { Often }\end{array}$ & $\begin{array}{c}103 \\
31 \\
26 \\
6\end{array}$ & $\begin{array}{c}62.0 \\
18.7 \\
15.7 \\
3.6\end{array}$ \\
\hline Do you work part time or full time & $\begin{array}{l}\text { Full time } \\
\text { Part-time }\end{array}$ & $\begin{array}{c}151 \\
15\end{array}$ & $\begin{array}{c}91.0 \\
9.0\end{array}$ \\
\hline Work pattern & $\begin{array}{c}\text { Fixed hours } \\
\text { Flexi hours } \\
\text { Shift work }\end{array}$ & $\begin{array}{c}116 \\
37 \\
13\end{array}$ & $\begin{array}{c}69.9 \\
22.3 \\
7.8\end{array}$ \\
\hline Work type & $\begin{array}{c}\text { Permanent } \\
\text { Temporary/casual } \\
\text { Fixed contract }\end{array}$ & $\begin{array}{c}154 \\
5 \\
7 \\
\end{array}$ & $\begin{array}{c}92.8 \\
3.0 \\
4.2 \\
\end{array}$ \\
\hline
\end{tabular}

\subsection{The Survey}

An online survey was carried out using Qualtrics software. The complete survey is shown in the supplementary material (link below) and the measures summarised in the next section: https://www.researchgate.net/publication/329311391_SURVEY_-

\section{_SHORT_MEASURES_OF_ORGANISATIONAL_COMMITMENT_CITIZENSHIP_BEHAVIOU R_AND_OTHER_EMPLOYEE_ATTITUDES_AND_BEHAVIOURS_ASSOCIATIONS_WITH_ WELL-BEING}

\subsection{Measures}

Psychological Contract Fulfilment (global) was measured using a scale adopted from Conway and Briner (2002). The measure assessed the general perceptions of Psychological Contract Fulfilment. An example was: "In general, this organisation has kept its promises to me about what I will get from them." Organisational commitment was measured using the Affective, Normative and Continuance Commitment Scale (Meyer and Allen, 1997). This scale comprised 3-dimensions which are affective, normative and continuance commitment. Affective commitment refers to the emotional attachment 
between the employee and the organisation. An employee tends to give full loyalty to the organisation and will put in an extra effort to achieve the organisation's goals. Normative commitment refers to the obligation given to stay with their current organisation. The obligation is the responsibility of one employee and they should obey to the organisation's goals, values and norms. On the other hand, continuance commitment reflects the responsibility of employees to stay with the organisation whereby if they leave, it will affect the development and well-being of the organisation. However, in this research, only one dimension of the organisational commitment which is affective commitment as most of the literature shows that it's related significantly with the psychological contract.

In this research, work-life balance was measured using the Work-Family and Family-Work Conflict scale developed by Netemeyer et al. (1996). Work-family conflict refers to any work demands and duties that affect employee's life at home. In contrast, family-work conflict refers to any problems related to the family that have a negative effect on duties and responsibilities at workplace.

Job insecurity was measured using 4-items developed by De Witte (2000). This scale is measured through 2-dimensions, which are affective and cognitive components related to insecurity in the person's current work. The four items can be combined together as a single dimension by summing all the items.

Motivation was measured using the Cassidy and Lynn Achievement Motivation (CLAM) scale (Cassidy and Lynn, 1989). This scale is based on 3-dimensions which are ethics, excellence and mastery. Ethics achievement is an individual desire to work earnestly and it is related to an individual's values and attitudes toward their job. Excellence motivation refers to an individual's desire to do his or her work the best he or she can do based on their ability and standard. Finally, mastery motivation refers to the desire of individuals to solve every problem faced until it is completed successfully. In the present study, the Work Effort Scale developed by De Cooman et al. (2009) was used. This scale consists of 10-items which measure three dimensions of work effort, namely intensity, direction and persistence. These dimensions were summed to give an overall work effort score.

Organisational Citizenship Behaviour was assessed using the scale developed by Podsakoff et al. (1990). This scale comprised 5-dimensions, namely altruism, conscientiousness, courtesy, civic virtue, and sportsmanship. In this study, intention to quit/ leave was measured using the scale developed by Kuvaas (2006). This scale contains 5-items and asks general questions about intention to leave the current job.

Single items of some of the concepts examined here (job satisfaction; job security; work-life balance) have already been developed as part of the validation of the WPQ. The following new short scales were developed from the above longer scales (affective commitment; work effort; intention to quit; and organisational citizen ship behaviour): 
Affective commitment:

To what extent do you agree or disagree with each of the following statements (Please circle one number for each)

1. I feel that I am emotionally attached with my organisation (for example: I love and I am proud of my organisation, my organisation's problems are mine, I feel I belong to my organisation etc.).
$1 \ldots \ldots . . .2$
3.
4.
5 .
6 .
7.
8
.9. 10

2. How much loyalty would you say you feel toward the organisation you work for, as a whole? Please circle one number only.
A lot of loyalty
Some loyalty
Only a little loyalty
Not at all loyalty
1
2 3. . .4

3. Are you proud to tell people who you work for? Please circle one number only.

Very proud indeed Quite proud A little proud Not all proud

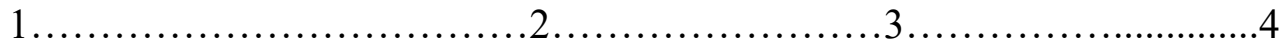

\section{Work Effort:}

To what extent do you agree or disagree with each of the following statements (Please circle one number for each)

1. In general, I feel that I put in an optimum effort to do my work (for example: I do my best to get work done in the best way, I do not give up quickly, I work hard etc.).

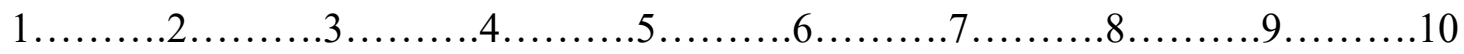

2. Which of the following statements best describes your current feelings about how much effort you put into work or how hard you work? Please circle one box only.

I am not working particularly hard I am working quite hard

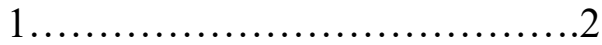

I am working very hard I am working as I can and could not imagine being able to work any harder

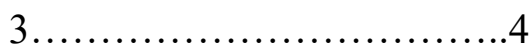

Organisational Citizenship Behaviour:

To what extent do you agree or disagree with each of the following statements (Please circle one number for each) 
1. I feel that I am an altruistic employee in my workplace (for example: helping co-workers with heavy workloads, helping new workers to adapt within the organisation, always being ready to offer help to those around me).

$1 \ldots \ldots . . .2 \ldots \ldots . . .3$

.4.

.5

6 .

7

$8 \ldots \ldots . . . .9$.

2. I feel that I am a courteous person in my workplace (for example: I try to avoid problems with another worker, I respect others' rights, I am always considering the impact of my actions on coworkers).

$1 \ldots \ldots \ldots . . . \ldots \ldots . . .3$

4

.5

.6.

.7

8

.9 .10

3. I feel that I am a conscientious employee for my organisation (for example: working beyond office hours even though not being asked to, being punctual and obeying the organisation's rules and regulations)

$1 \ldots \ldots . . .2$

$3 \ldots \ldots . . .4$

$.5 \ldots \ldots . .66$

.7 .

8

9

4. I feel that I am willing to tolerate with inevitable inconveniences and impositions of work without complaining (for example: accepting and doing any drastic works, accepting organisation changes, not complaining or finding fault with what the organisation is doing).

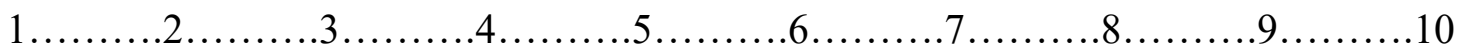

5. I feel that I am involved constructively and comprehensively with my organisation (for example: attending meetings that are not compulsory but are considered important, attending functions that help improve organisation image even if it is not compulsory, being up-to-date with organisation changes and reading all organisation communications).

$1 \ldots \ldots \ldots . \ldots \ldots \ldots . . \ldots \ldots \ldots 4 \ldots \ldots \ldots .5 \ldots \ldots \ldots 6 \ldots \ldots . . \ldots \ldots \ldots 8 \ldots \ldots \ldots 9 \ldots \ldots .10$

DRIVE model variables from the WPQ:

The DRIVE model was used as the theoretical framework of the research and the original variables used in previous research were also included (Mark and Smith, 2012a, 2012b). These variables were effort, demands, control, support, reward, coping styles, attributional style, job satisfaction, anxiety and depression. Additional variables were included because other factors fit into this framework and add to a multi-dimensional approach. The HSE Management Standards represent the current UK recommended method of measuring well-being psychosocial hazards in the workplace (Black, 2008), other variables not already accounted for by the DCS and ERI models were included. 
These variables were role understanding, supervisor relationship and consultation on change. Bullying has also been identified as an important risk factor (Quine, 1999).

While individual differences in coping and attributional style were included in the DRIVE model, personality variables represent a significant omission, especially as personality has been shown to be the most important predictor of subjective well-being outcomes (Diener et al., 2003). The most commonly used model of personality is the "Big 5" model (Steel et al., 2008) and extraversion and neuroticism in particular have demonstrated significant relationships with positive and negative wellbeing outcomes, although specific associations with other big 5 variables have also been demonstrated (Hayes and Joseph, 2003). Extraversion, emotional stability, conscientiousness, agreeableness, and openness were therefore included. Use of these broad personality characteristics may be an oversimplification of the associations between personality and well-being (Diener et al., 2003) and may have less predictive validity than the use of specific personality variables (Schimmack et al., 2004). Other frequently cited variables associated with well-being are optimism, self-esteem, and selfefficacy. Optimism has frequently been associated with life satisfaction and happiness (Sharpe et al., 2011; Scheier et al., 1994; Kluemper et al., 2009). Others (e.g. Bandura, 1988) suggest that perceived self-inefficacy is the major source of reduced well-being. Loss of self-esteem has been shown to be an important variable in depression, negative affect, and stress (Lee-Flynn et al., 2011). Optimism, selfefficacy and self-esteem have also been suggested as potential buffers against negative well-being outcomes (Lee-Flynn et al., 2011) and reviews of well-being measures (Parkinson, 2007). Deneve and Cooper (1998) conclude that the most important personality variables appear to be those that are concerned with making healthy attributions. Self-esteem, optimism, and self-efficacy represent positive attributions related to one's self, one's future, and one's abilities respectively. Measures of optimism, self-esteem, and self-efficacy were therefore also included.

Outcomes represented the well-being variables implicated in policy (Knapp et al., 2006; Waldron, 2010; Wismar et al., 2013) and previous well-being research (e.g. Smith et al., 2004; Mark \& Smith, 2012a; Smith et al., 2009). Stress, depression, and anxiety were included the UK monitored negative psychological well-being outcomes (e.g. in the Labour Force Survey) and because they are frequently assessed well-being outcomes in the workplace (e.g. Smith et al., 2009). In order to assess subjective wellbeing (SWB), positive mood, negative mood, and life satisfaction were also included. SWB has been shown to be distinct from mental health outcomes such as depression and anxiety (Headey and Wearing, 1989) and may be useful as an outcome for those who may not recognise anxiety or depression in themselves or may not want to report it. Furthermore, the subjective element of wellbeing and satisfaction judgements have been suggested as integral parts of a holistic concept of wellbeing (Diener, 1984; Diener et al., 1998; Waldron, 2010). Measures relating to perceived stress and 
satisfaction both at work and outside work were recorded. Hassles and uplifts were also measured to complement the job characteristics.

\section{RESULTS}

\subsection{Stages of Analysis}

There were three main stages in the analyses. The first examined the descriptive statistics of the variables to check that there was appropriate variation in scores. The second examined the construct validity of the new items by examining the association between the new short items and the original longer scales. Correlations between the scale total scores and new single items were computed. These were then compared with the correlations of individual items from the original scale and the total score. The final set of analyses examined associations between the original long scales, the new single items and the WPQ variables. The aim of these analyses was to compare the predictive validity of the long and short measures.

\subsection{Descriptive Statistics for Variables: Work Characteristics, Coping Styles, Personality,}

\section{Psychological Contract Fulfilment, Job Attitudes, Work Behaviours and Well-Being}

The descriptive statistics for the complete set of variables are shown in Table 2. Generally, there was appropriate variation in the scores, which made a correlational approach appropriate.

Table 2. Descriptive Statistic Analysis of Work Characteristics, Coping Styles, Personality, Psychological Contract Fulfilment, Job Attitudes, Work Behaviours and Well-Being

\begin{tabular}{|c|c|c|c|c|c|}
\hline Variable & $\mathbf{N}$ & Mean & Standard Deviation & Minimum & Maximum \\
\hline $\begin{array}{l}\text { Job characteristics: } \\
\text { Effort } \\
\text { Demands } \\
\text { Role understanding } \\
\text { Consultation of change } \\
\text { Workplace bullying } \\
\text { Control } \\
\text { Colleagues support } \\
\text { Supervisor relationship } \\
\text { Reward }\end{array}$ & $\begin{array}{l}166 \\
166 \\
166 \\
166 \\
166 \\
166 \\
166 \\
166 \\
166\end{array}$ & $\begin{array}{l}4.11 \\
4.19 \\
2.69 \\
4.21 \\
1.98 \\
6.81 \\
7.34 \\
7.15 \\
6.42\end{array}$ & $\begin{array}{l}2.61 \\
2.57 \\
2.05 \\
2.57 \\
1.85 \\
2.25 \\
2.06 \\
2.46 \\
2.28\end{array}$ & $\begin{array}{l}1.00 \\
1.00 \\
1.00 \\
1.00 \\
1.00 \\
1.00 \\
1.00 \\
1.00 \\
1.00\end{array}$ & $\begin{array}{c}10.00 \\
10.00 \\
10.00 \\
10.00 \\
9.00 \\
10.00 \\
10.00 \\
10.00 \\
10.00\end{array}$ \\
\hline $\begin{array}{l}\text { Coping Styles: } \\
\text { Problem-focused } \\
\text { Social support } \\
\text { Avoidance } \\
\text { Self-blame } \\
\text { Wishful thinking } \\
\end{array}$ & $\begin{array}{l}166 \\
166 \\
166 \\
166 \\
166 \\
\end{array}$ & $\begin{array}{l}7.63 \\
6.06 \\
4.41 \\
6.08 \\
3.73 \\
\end{array}$ & $\begin{array}{l}1.85 \\
2.32 \\
2.46 \\
2.54 \\
2.34 \\
\end{array}$ & $\begin{array}{l}1.00 \\
1.00 \\
1.00 \\
1.00 \\
1.00 \\
\end{array}$ & $\begin{array}{l}10.00 \\
10.00 \\
10.00 \\
10.00 \\
10.00\end{array}$ \\
\hline $\begin{array}{l}\text { Personality: } \\
\text { Openness } \\
\text { Conscientiousness } \\
\text { Extraversion } \\
\text { Agreeableness } \\
\text { Emotional stability } \\
\text { Self-efficacy } \\
\text { Self-esteem } \\
\text { Optimism/pessimism }\end{array}$ & $\begin{array}{l}166 \\
166 \\
166 \\
166 \\
166 \\
166 \\
166 \\
166\end{array}$ & $\begin{array}{l}7.72 \\
8.25 \\
6.19 \\
7.90 \\
8.01 \\
7.54 \\
7.90 \\
7.52\end{array}$ & $\begin{array}{l}1.92 \\
1.67 \\
2.75 \\
1.96 \\
1.92 \\
2.28 \\
1.88 \\
2.13\end{array}$ & $\begin{array}{l}1.00 \\
1.00 \\
1.00 \\
1.00 \\
1.00 \\
1.00 \\
1.00 \\
1.00\end{array}$ & $\begin{array}{l}10.00 \\
10.00 \\
10.00 \\
10.00 \\
10.00 \\
10.00 \\
10.00 \\
10.00\end{array}$ \\
\hline
\end{tabular}




\begin{tabular}{|c|c|c|c|c|c|}
\hline Psychological contract & 166 & 52.88 & 12.04 & 19.00 & 76.00 \\
\hline $\begin{array}{l}\text { Affective commitment } \\
\text { Employment relations } \\
\text { Work security }\end{array}$ & $\begin{array}{l}166 \\
166 \\
166\end{array}$ & $\begin{array}{l}6.13 \\
3.88 \\
3.05 \\
\end{array}$ & $\begin{array}{l}2.61 \\
0.80 \\
2.31 \\
\end{array}$ & $\begin{array}{l}1.00 \\
1.00 \\
1.00 \\
\end{array}$ & $\begin{array}{l}10.00 \\
10.00 \\
10.00 \\
\end{array}$ \\
\hline $\begin{array}{l}\text { Motivation 1 } \\
\text { Motivation } 2 \\
\text { Work effort } \\
\text { Altruism } \\
\text { Courtesy } \\
\text { Conscientiousness } \\
\text { Sportsmanship } \\
\text { Civic virtue } \\
\text { Intention to quit }\end{array}$ & $\begin{array}{l}166 \\
166 \\
166 \\
166 \\
166 \\
166 \\
166 \\
166 \\
166\end{array}$ & $\begin{array}{l}7.25 \\
6.14 \\
8.29 \\
7.79 \\
8.05 \\
7.95 \\
7.36 \\
7.34 \\
5.05\end{array}$ & $\begin{array}{l}2.11 \\
2.63 \\
1.53 \\
1.73 \\
1.96 \\
1.83 \\
1.98 \\
1.91 \\
3.11\end{array}$ & $\begin{array}{l}1.00 \\
1.00 \\
1.00 \\
1.00 \\
1.00 \\
1.00 \\
1.00 \\
1.00 \\
1.00\end{array}$ & $\begin{array}{l}10.00 \\
10.00 \\
10.00 \\
10.00 \\
10.00 \\
10.00 \\
10.00 \\
10.00 \\
10.00\end{array}$ \\
\hline Work-life balance 1 & 166 & 4.02 & 2.47 & 1.00 & 10.00 \\
\hline Work-life balance 2 & 166 & 2.95 & 1.91 & 1.00 & 10.00 \\
\hline General well-being 1 & 166 & 7.09 & 2.34 & 1.00 & 10.00 \\
\hline General well-being 2 & 166 & 7.61 & 2.08 & 1.00 & 10.00 \\
\hline Flourishing & 166 & 7.40 & 2.23 & 1.00 & 10.00 \\
\hline Positive affect & 166 & 7.48 & 2.21 & 1.00 & 10.00 \\
\hline Negative affect & 166 & 3.60 & 2.62 & 1.00 & 10.00 \\
\hline Life satisfaction & 166 & 7.36 & 2.24 & 1.00 & 10.00 \\
\hline Job satisfaction & 166 & 6.99 & 2.26 & 1.00 & 10.00 \\
\hline General health & 166 & 3.00 & 0.75 & 1.00 & 6.00 \\
\hline Uplifting & 166 & 6.60 & 2.09 & 1.00 & 10.00 \\
\hline Hassle & 166 & 4.14 & 2.15 & 1.00 & 10.00 \\
\hline Anxiety & 166 & 4.28 & 2.39 & 1.00 & 10.00 \\
\hline Depression & 166 & 3.20 & 2.31 & 1.00 & 10.00 \\
\hline Job stress & 166 & 4.93 & 2.33 & 1.00 & 10.00 \\
\hline Outside work stress 1 & 166 & 2.17 & 2.17 & 1.00 & 10.00 \\
\hline Outside work stress 2 & 166 & 4.22 & 2.73 & 1.00 & 10.00 \\
\hline
\end{tabular}

\subsection{Construct Validity of New Single Items (Affective Commitment, Work Effort,} Turnover Intention and Organisational Citizenship Behaviour)

\section{Affective commitment}

Table 3 shows that the correlation between the total affective commitment scale and the new single item was 0.805 . The single item was also significantly correlated with the individual items of the original scale.

Table 3. Construct Validity of Affective Commitment Single Item using Item-Total Correlation

Analysis

\begin{tabular}{|l|c|c|c|c|c|c|c|c|c|}
\hline Item & $\mathbf{( 1 )}$ & $\mathbf{( 2 )}$ & $\mathbf{( 3 )}$ & $\mathbf{( 4 )}$ & $\mathbf{( 5 )}$ & $\mathbf{( 6 )}$ & $\mathbf{( 7 )}$ & $\mathbf{( 8 )}$ & $\mathbf{( 9 )}$ \\
\hline $\mathbf{A C ~ ( 1 )}$ & $\mathbf{1}$ & & & & & & & & \\
\hline $\mathbf{A C}(\mathbf{2})$ & $.630^{* *}$ & $\mathbf{1}$ & & & & & & & \\
\hline $\mathbf{A C}(\mathbf{3})$ & $.390^{* *}$ & $.576^{* *}$ & $\mathbf{1}$ & & & & & & \\
\hline $\mathbf{A C}(\mathbf{4})$ & $.341^{* *}$ & $.198^{*}$ & $.192^{*}$ & $\mathbf{1}$ & & & & & \\
\hline $\mathbf{A C}(\mathbf{5})$ & $.518^{* *}$ & $.491^{* *}$ & $.442^{* *}$ & $.318^{* *}$ & $\mathbf{1}$ & & & & \\
\hline $\mathbf{A C}(\mathbf{6})$ & $.549^{* *}$ & $.527^{* *}$ & $.516^{* *}$ & $.257^{* *}$ & $.786^{* *}$ & $\mathbf{1}$ & & & \\
\hline $\mathbf{A C}(\mathbf{7})$ & $.597^{* *}$ & $.594^{* *}$ & $.530^{* *}$ & $.222^{* *}$ & $.562^{* *}$ & $.695^{* *}$ & $\mathbf{1}$ & & \\
\hline $\mathbf{A C ~ ( 8 )}$ & $.581^{* *}$ & $.542^{* *}$ & $.611^{* *}$ & $.301^{* *}$ & $.738^{* *}$ & $.759^{* *}$ & $.676^{* *}$ & $\mathbf{1}$ & \\
\hline $\mathbf{A C}(\mathbf{T})(\mathbf{9})$ & $.730^{* *}$ & $.763^{* *}$ & $.709^{* *}$ & $.156^{*}$ & $.790^{* *}$ & $.858^{* *}$ & $.826^{* *}$ & $.859^{* *}$ & $\mathbf{1}$ \\
\hline $\mathbf{A C}(\mathbf{S i})(\mathbf{1 0})$ & $.566^{* *}$ & $.606^{* *}$ & $.687^{* *}$ & $.324^{* *}$ & $.592^{* *}$ & $.712^{* *}$ & $.772^{* *}$ & $.724^{* *}$ & $.805^{* *}$ \\
\hline
\end{tabular}

$* \mathrm{p}<.05$

$* * \mathrm{p}<0.01$

(T) Summation of the original items into a total score of construct

(Si) New single item 


\section{Work Effort}

The correlation between the work effort single item and total score of the longer scale was 0.733. Correlations between the new single item and the individual items of the original scale were also significant (see Table 4).

Table 4. Construct Validity of Work Effort Single Item using Item-Total Correlation Analysis

\begin{tabular}{|c|c|c|c|c|c|c|c|c|c|c|c|}
\hline Item & (1) & (2) & (3) & (4) & (5) & (6) & $(7)$ & (8) & (9) & (10) & (11) \\
\hline WE (1) & 1 & & & & & & & & & & \\
\hline WE (2) & $.632 * *$ & 1 & & & & & & & & & \\
\hline WE (3) & $.654 * *$ & $.741 * *$ & 1 & & & & & & & & \\
\hline WE (4) & $.556 * *$ & $.663 * *$ & $.720 * *$ & 1 & & & & & & & \\
\hline WE (5) & $.573 * *$ & $.676 * *$ & $.711 * *$ & $.751 * *$ & 1 & & & & & & \\
\hline WE (6) & $.586 * *$ & $.793 * *$ & $.765 * *$ & $.756 * *$ & $.814 * *$ & 1 & & & & & \\
\hline WE (7) & $.613 * *$ & $.735 * *$ & $.694 * *$ & $.679 * *$ & $.738 * *$ & $.703 * *$ & 1 & & & & \\
\hline WE (8) & $.544 * *$ & $.765 * *$ & $.681 * *$ & $.680 * *$ & $.689 * *$ & $.789 * *$ & $.739 * *$ & 1 & & & \\
\hline WE (9) & $.580 * *$ & $.745 * *$ & $.719 * *$ & $.650 * *$ & $.695 * *$ & $.771 * *$ & $.719 * *$ & $.777 * *$ & 1 & & \\
\hline WE (10) & $.569 * *$ & $.695 * *$ & $.676 * *$ & $.674 * *$ & $.648 * *$ & $.715^{* * *}$ & $.726 * *$ & $.679 * *$ & $.688 * *$ & 1 & \\
\hline WE (T) (11) & $.754 * *$ & $.877 * *$ & $.865 * *$ & $.831 * *$ & $.852 * *$ & $.900 * *$ & $.866 * *$ & $.864 * *$ & $.863 * *$ & $.864 * *$ & 1 \\
\hline WE (Si) (12) & $.553 * *$ & $.626 * *$ & $.622 * *$ & $.613 * *$ & $.540 * *$ & $.629 * *$ & $.609 * *$ & $.715 * *$ & $.684 * *$ & $.627 * *$ & $.733 * *$ \\
\hline
\end{tabular}

$* \mathrm{p}<.05$

$* * \mathrm{p}<0.01$

(T) Summation of the original items into a total score of construct

(Si) New single item

\section{Intention to Leave the Job}

The correlation between intention to quit single item and total score of the longer scale was 0.817. Correlations between the new single item and the individual items of the original scale were also significant (see Table 5).

Table 5. Construct Validity of Turnover Intention Single Item using Item-Total Correlation Analysis

\begin{tabular}{|c|c|c|c|c|c|c|}
\hline $\mathbf{I t e m}$ & $\mathbf{( 1 )}$ & $\mathbf{( 2 )}$ & $\mathbf{( 3 )}$ & $\mathbf{( 4 )}$ & $\mathbf{( 5 )}$ & $\mathbf{( 6 )}$ \\
\hline $\mathbf{T i}(\mathbf{1})$ & $\mathbf{1}$ & & & & & \\
\hline $\mathbf{T i}(\mathbf{2})$ & $.877^{* *}$ & $\mathbf{1}$ & & & & \\
\hline $\mathbf{T i}(\mathbf{3})$ & $.812^{* *}$ & $.778^{* *}$ & $\mathbf{1}$ & & & \\
\hline $\mathbf{T i}(\mathbf{4})$ & $.789^{* *}$ & $.838^{* *}$ & $.769^{* *}$ & $\mathbf{1}$ & & \\
\hline $\mathbf{T i}(\mathbf{5})$ & $.717^{* *}$ & $.765^{* *}$ & $.707^{* *}$ & $.769^{* *}$ & $\mathbf{1}$ & \\
\hline $\mathbf{T i} \mathbf{( T )}(\mathbf{6})$ & $.923^{* *}$ & $.935^{* *}$ & $.899^{* *}$ & $.917^{* *}$ & $.868^{* *}$ & $\mathbf{1}$ \\
\hline $\mathbf{T i} \mathbf{( S i )}(\mathbf{7})$ & $.732^{* *}$ & $.717^{* *}$ & $.797^{* *}$ & $.756^{* *}$ & $.703^{* *}$ & $.817^{* *}$ \\
\hline
\end{tabular}

$* \mathrm{p}<.05$

$* * \mathrm{p}<0.01$

(T) Summation of the original items into a total score of construct

(Si) New single item (reverse scored)

Organisational Citizenship Behaviour

The correlations between the new single items and the total scores for the sub-scales are shown in Table 6. These were all significant but were lower than those seen in the previous analyses (range 0.448 to 0.679 ). Again, all the correlations between the new single items and original individual items were significant. 
Overall, these analyses show that the new single items were significantly correlated with the original longer scales. The next set of analyses examine their associations with the WPQ variables (i.e. their predictive validity).

Table 6: Construct Validity of Organisational Citizenship Behaviour (OCB) Single Items using Item-Total Correlation Analysis

\begin{tabular}{|c|c|c|c|c|c|c|}
\hline Item & (1) & (2) & (3) & (4) & (5) & (6) \\
\hline \multicolumn{7}{|l|}{ Altruism } \\
\hline Alt (1) & 1 & & & & & \\
\hline Alt (2) & $.666 * *$ & 1 & & & & \\
\hline Alt (3) & $.603 * *$ & $.674 * *$ & 1 & & & \\
\hline Alt (4) & $.551 * *$ & $.745 * *$ & $.612 * *$ & 1 & & \\
\hline Alt (5) & $.592 * *$ & $.814 * *$ & $.654 * *$ & $.778 * *$ & 1 & \\
\hline Alt (T) (6) & $.799 * *$ & $.909 * *$ & $.824 * *$ & $.857 * *$ & $.898 * *$ & 1 \\
\hline Alt (Si) (7) & $.530 * *$ & $.587 * *$ & $.630 * *$ & $.509 * *$ & $.652 * *$ & $.679 * *$ \\
\hline \multicolumn{7}{|l|}{ Courtesy } \\
\hline Court (1) & 1 & & & & & \\
\hline Court (2) & $.485 * *$ & 1 & & & & \\
\hline Court (3) & $.496 * *$ & $.591 * *$ & 1 & & & \\
\hline Court (4) & $.440 * *$ & $.639 * *$ & $.532 * *$ & 1 & & \\
\hline Court (5) & $.399 * *$ & $.577 * *$ & $.529 * *$ & $.601 * *$ & 1 & \\
\hline Court (T) (6) & $.722 * *$ & $.831 * *$ & $.810^{* * *}$ & $.798 * *$ & $.784 * *$ & 1 \\
\hline Court (Si) (7) & $.363 * *$ & $.578 * *$ & $.521 * *$ & $.529 * *$ & $.529 * *$ & $.637 * *$ \\
\hline \multicolumn{7}{|c|}{ Conscientiousness } \\
\hline Cons (1) & 1 & & & & & \\
\hline Cons (2) & $.190^{*}$ & 1 & & & & \\
\hline Cons (3) & $.288 * *$ & $.410 * *$ & 1 & & & \\
\hline Cons (4) & $.232 * *$ & $.392 * *$ & $.571 * *$ & 1 & & \\
\hline Cons (5) & $.195 *$ & $.183 *$ & $388 * *$ & $.449 * *$ & 1 & \\
\hline Cons (T) (6) & $.609 * *$ & $.649 * *$ & $.747 * *$ & $.748 * *$ & $.642 * *$ & 1 \\
\hline Cons ( $\mathbf{S i})(7)$ & $.337 * *$ & $.358 * *$ & $.451 * *$ & $.502 * *$ & $.337 * *$ & $.580 * *$ \\
\hline \multicolumn{7}{|l|}{ Sportsmanship } \\
\hline Sports (1) & 1 & & & & & \\
\hline Sports (2) & $.615^{* *}$ & 1 & & & & \\
\hline Sports $(3)$ & $.427 * *$ & $.591 * *$ & 1 & & & \\
\hline Sports (4) & $.257 * *$ & $.319 * *$ & $.383 * *$ & 1 & & \\
\hline Sports (5) & $.612 * *$ & $.633 * *$ & $.527 * *$ & $.230 * *$ & 1 & \\
\hline Sports (T) (6) & $.742 * *$ & $.815 * *$ & $.780 * *$ & $.638 * *$ & $.780 * *$ & 1 \\
\hline Sports $(\mathrm{Si})(7)$ & $.346 * *$ & $.482 * *$ & $357 * *$ & .107 & $.453 * *$ & $.448 * *$ \\
\hline \multicolumn{7}{|l|}{ Civic Virtue } \\
\hline Civic (1) & 1 & & & & & \\
\hline Civic (2) & $.519 * *$ & 1 & & & & \\
\hline Civic (3) & $.313 * *$ & $.300 * *$ & 1 & & & \\
\hline Civic (4) & $.237 * *$ & $.215 * *$ & $.480 * *$ & 1 & & \\
\hline Civic (T) (5) & $.744 * *$ & $.762 * *$ & $.689 * *$ & $.647 * *$ & 1 & \\
\hline Civic (Si) (6) & $.500 * *$ & $.523 * *$ & $363 * *$ & $.361 *$ & $.623 * *$ & 1 \\
\hline
\end{tabular}

$* \mathrm{p}<.05$

$* * \mathrm{p}<0.01$

(T) Summation of the original items into a total score of construct

( $\mathrm{Si}$ ) New single item 


\subsection{Associations Between WPQ variables and Psychological Contract Fulfilment}

\section{Work Characteristics and Psychological Contract Fulfilment}

The correlations between work characteristics and Psychological Contract Fulfilment are shown in Table 7. Psychological Contract Fulfilment was negatively correlated with demands and other negative job characteristics and was positively correlated with control, support and rewards (resources).

\section{Individual Differences and Psychological Contract Fulfilment}

The correlations between individual differences and Psychological Contract Fulfilment are shown in Table 8. Psychological Contract Fulfilment was negatively correlated with avoidance coping and was positively correlated with the Big 5 dimensions (openness; conscientiousness; extraversion; agreeableness; and emotional stability) and the positive personality dimensions of self-esteem, selfefficacy, and optimism.

\section{Well-being Outcomes and Psychological Contract Fulfilment}

The correlations between well-being outcomes and Psychological Contract Fulfilment are shown in Table 9. Psychological Contract Fulfilment was positively correlated with well-being both at work (e.g. job satisfaction) and in life generally (e.g. positive affect; life satisfaction). In contrast, it was negatively correlated with low well-being scores both at work (e.g. job stress) and in life generally (e.g. negative affect; stress outside of work; anxiety and depression).

Table 7. The Relationship between Work Demands, Work Resources and Psychological Contract Fulfilment

\begin{tabular}{|l|c|c|c|c|c|c|c|c|c|}
\hline Variable & $\mathbf{( 1 )}$ & $\mathbf{( 2 )}$ & $\mathbf{( 3 )}$ & $\mathbf{( 4 )}$ & $\mathbf{( 5 )}$ & $\mathbf{( 6 )}$ & $\mathbf{( 7 )}$ & $\mathbf{( 8 )}$ & $\mathbf{( 9 )}$ \\
\hline Extrinsic effort (1) & $\mathbf{1}$ & & & & & & & & \\
\hline Work Demand (2) & $.619^{* *}$ & $\mathbf{1}$ & & & & & & & \\
\hline Role understanding (3) & $.309^{* *}$ & $.331^{* *}$ & $\mathbf{1}$ & & & & & & \\
\hline $\begin{array}{l}\text { Consultation of change } \\
(\mathbf{4})\end{array}$ & $.257^{* *}$ & $.460^{* *}$ & $.316^{* *}$ & $\mathbf{1}$ & & & & & \\
\hline Work bullying (5) & $.318^{* *}$ & $.402^{* *}$ & $.471^{* *}$ & $.239^{* *}$ & $\mathbf{1}$ & & & & \\
\hline Work control (6) & -.205 & -.331 & $-.202^{* *}$ & $-.269^{* *}$ & $-.226^{* *}$ & $\mathbf{1}$ & & & \\
\hline Colleagues support (7) & -.094 & $-.185^{*}$ & $-.324^{* *}$ & $-.178^{*}$ & $-.208^{*}$ & $.549^{* *}$ & $\mathbf{1}$ & & \\
\hline Supervisor support (8) & -.196 & $-.212^{* *}$ & $-.319^{* *}$ & $-.284^{* *}$ & $-.356^{* *}$ & $.483^{* *}$ & $.649^{* *}$ & $\mathbf{1}$ & \\
\hline Reward (9) & -.149 & $-.286^{* *}$ & $-.167^{* *}$ & $-.335^{* *}$ & $-.176^{*}$ & $.596^{* *}$ & $.578^{* *}$ & $.653^{* *}$ & $\mathbf{1}$ \\
\hline $\begin{array}{l}\text { Psychological contract } \\
(\mathbf{1 0}) \quad-.262^{* *}\end{array}$ &.$- .392^{* *}$ & $-.349^{* *}$ & $-.463^{* *}$ & $-.337^{* *}$ & $.421^{* *}$ & $.544^{* *}$ & $.614^{* *}$ & $.674^{* *}$ \\
\hline \multicolumn{1}{c}{$* \mathrm{p}<.05$} & & & & & & & & \\
\hline
\end{tabular}


Table 8. The Relationship between Coping Styles, Personality and Psychological Contract Fulfilment

\begin{tabular}{|c|c|c|c|c|c|c|c|c|c|c|c|c|c|c|c|}
\hline$\underset{ \pm}{ \pm}$ & & & & & & & & & & & & & & 一 & \\
\hline$\cong$ & & & & & & & & & & & & & - & & $*$ \\
\hline$\Xi$ & & & & & & & & & & & & 一 & 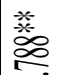 & 养 & \\
\hline$\supseteqq$ & & & & & & & & & & & 一 & 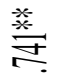 & $\begin{array}{l}\text { 蓄 } \\
\text { 。 }\end{array}$ & 菜 & \\
\hline$\theta$ & & & & & & & & & & - & 恧 & 香 & 㥣 & 蓉 & \\
\hline$\sigma$ & & & & & & & & & - & $\frac{\text { 蓄 }}{\rightleftharpoons}$ & 蓄 & 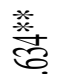 & 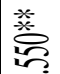 & 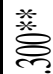 & \\
\hline$\infty$ & & & & & & & & 一 & 萻 & $\stackrel{\text { 蓄 }}{\underset{9}{3}}$ & 㸓 & 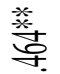 & $\frac{\text { 悉 }}{\stackrel{5}{?}}$ & 莘 & \\
\hline$E$ & & & & & & & 一 & 惫 & $\begin{array}{l}\text { 蓄 } \\
\text { 宫 }\end{array}$ & 窇 & 䔄 & $\underbrace{}_{\text {䔄 }}$ & $\begin{array}{l}\text { 荥 } \\
\stackrel{2}{n} \text { ? }\end{array}$ & 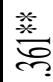 & \\
\hline$\theta$ & & & & & & 一 & 点 & 萻 & 䔄 & 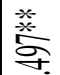 & 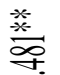 & 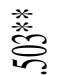 & 蓄 & 善 & \\
\hline$\sqrt{2}$ & & & & & 一 & 旁 & 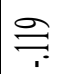 & 茎 & $\stackrel{\infty}{\infty}$ & 䔄 & 誉 & 守 & 8 & 糙 & \\
\hline$\Phi$ & & & & 一 & 蒸 & 坟 & 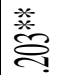 & हి & 孚 & $\stackrel{*}{\stackrel{*}{\Xi}}$ & 官 & 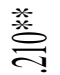 & 芯 & $\stackrel{\circ}{\partial}$ & \\
\hline$\approx$ & & & 一 & 芠 & 藁 & 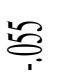 & 르 & 羙 & $\stackrel{n}{o}$ & 옹 & 荽 & 蒽 & 薏 & 5 & \\
\hline व & & 一 & 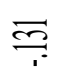 & 蒽 & $\equiv$ & 恖 & 茶 & 菩 & 恚 & 㝨 & 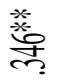 & 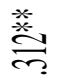 & $\frac{\text { * }}{\stackrel{*}{*}}$ & $\cong$ & \\
\hline$\equiv$ & 一 & 蒽 & 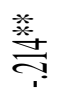 & $\cong$ & 荳 & 蓄矣 & 敨 & 菜 & 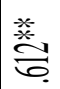 & $\sqrt{n}$ & $\frac{\text { 曾 }}{8}$ & 恶 & 菜 & 恶 & \\
\hline 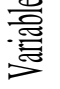 & $\equiv$ & a & 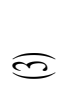 & $\Phi$ & 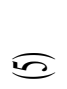 & $\theta$ & $E$ & $\infty$ & $\sigma$ & 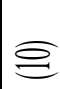 & $\Xi$ & $\Xi$ & $\approx$ & $\Xi$ & \\
\hline
\end{tabular}

(1): problem-focused, (2): social support, (3): self-blame, (4): wishful thinking, (5): avoidance, (6): openness, (7): conscientiousness, (8): extraversion, (9): agreeableness,

(10): emotional stability, (11): self-esteem, (12): self-efficacy, (13): optimism, (14): psychological contract. $* p<.05$

$* * p<0.01$ 
Table 9. The Relationship between Psychological Contract Fulfilment and Well-Being Outcomes

\begin{tabular}{|c|c|c|c|c|c|c|c|c|c|c|c|c|c|c|c|c|}
\hline $\begin{array}{l}\text { Varia } \\
\text { ble }\end{array}$ & (1) & (2) & (3) & (4) & (5) & (6) & (7) & (8) & (9) & (10) & (11) & (12) & (13) & (14) & $\begin{array}{c}(15 \\
)\end{array}$ & $\begin{array}{l}\text { (1 } \\
6)\end{array}$ \\
\hline \multicolumn{17}{|l|}{ (1) } \\
\hline (2) & .183 & 1 & & & & & & & & & & & & & & \\
\hline \multirow[t]{2}{*}{ (3) } & .827 & .717 & 1 & & & & & & & & & & & & & \\
\hline & $* *$ & $* *$ & & & & & & & & & & & & & & \\
\hline \multirow[t]{2}{*}{ (4) } & .804 & .786 & .754 & 1 & & & & & & & & & & & & \\
\hline & $* *$ & $* *$ & $* *$ & & & & & & & & & & & & & \\
\hline \multirow[t]{2}{*}{ (5) } & $\begin{array}{c}- \\
.296\end{array}$ & $\begin{array}{c}- \\
\\
.387\end{array}$ & .358 & $\begin{array}{c}- \\
.472\end{array}$ & 1 & & & & & & & & & & & \\
\hline & $* *$ & $* *$ & $* *$ & $* *$ & & & & & & & & & & & & \\
\hline \multirow[t]{2}{*}{ (6) } & .796 & .775 & .763 & .824 & - & 1 & & & & & & & & & & \\
\hline & & $* *$ & $* *$ & $* *$ & $\begin{array}{c}.398 \\
* *\end{array}$ & & & & & & & & & & & \\
\hline \multirow[t]{2}{*}{ (7) } & .482 & .374 & .420 & 447 & - & .446 & 1 & & & & & & & & & \\
\hline & $* *$ & $* *$ & $* *$ & $* *$ & .280 & $* *$ & & & & & & & & & & \\
\hline \multirow[t]{2}{*}{ (8) } & .350 & .258 & .313 & .360 & - & .403 & .097 & 1 & & & & & & & & \\
\hline & $* *$ & $* *$ & $* *$ & $* *$ & $.37^{*}$ & $* *$ & & & & & & & & & & \\
\hline \multirow[t]{2}{*}{ (9) } & .612 & .531 & .605 & .634 & - & .523 & .504 & .284 & 1 & & & & & & & \\
\hline & $* *$ & $* *$ & $* *$ & $* *$ & .320 & $* *$ & $* *$ & $* *$ & & & & & & & & \\
\hline \multirow[t]{3}{*}{ (10) } & - & - & - & - & .407 & - & - & - & - & 1 & & & & & & \\
\hline & .564 & .497. & .484 & .511 & $* *$ & .493 & .363 & 234 & .405 & & & & & & & \\
\hline & $* *$ & $* *$ & $* *$ & $* *$ & & $* *$ & $* *$ & $* *$ & $* *$ & & & & & & & \\
\hline \multirow[t]{3}{*}{ (11) } & - & - & - & - & .668 & - & - & - & - & .553 & 1 & & & & & \\
\hline & .554 & .442 & .543 & .522 & $* *$ & .548 & .343 & .478 & .419 & $* *$ & & & & & & \\
\hline & $* *$ & $* *$ & $* *$ & $* *$ & & $* *$ & $* *$ & $* *$ & $* *$ & & & & & & & \\
\hline \multirow[t]{3}{*}{ (12) } & - & - & - & - & .499 & - & - & - & - & .555 & .633 & 1 & & & & \\
\hline & .430 & .389 & .369 & .443 & $* *$ & .395 & .259 & .364 & .371 & $* *$ & $* *$ & & & & & \\
\hline & $* *$ & $* *$ & $* *$ & $* *$ & & $* *$ & $* *$ & $* *$ & $* *$ & & & & & & & \\
\hline \multirow[t]{3}{*}{ (13) } & - & - & - & - & .291 & - & - & - & - & .565 & .424 & .396 & 1 & & & \\
\hline & .332 & .211 & .273 & .292 & $* *$ & .267 & .377 & .157 & .234 & $* *$ & $* *$ & $* *$ & & & & \\
\hline & $* *$ & $* *$ & $* *$ & $* *$ & & $* *$ & $* *$ & $*$ & $* *$ & & & & & & & \\
\hline
\end{tabular}




\begin{tabular}{|c|c|c|c|c|c|c|c|c|c|c|c|c|c|c|c|c|}
\hline (14) & $\begin{array}{c}- \\
.345 \\
* *\end{array}$ & $\begin{array}{c}- \\
.346 \\
* *\end{array}$ & $\begin{array}{c}- \\
.217 \\
* *\end{array}$ & $\begin{array}{c}- \\
.306 \\
* *\end{array}$ & $\begin{array}{c}.249 \\
* *\end{array}$ & $\begin{array}{c}- \\
.314 \\
* *\end{array}$ & $\begin{array}{c}- \\
.328 \\
* *\end{array}$ & $\begin{array}{c}- \\
.124\end{array}$ & $\begin{array}{c}- \\
.142\end{array}$ & $\begin{array}{c}.454 \\
* *\end{array}$ & $\begin{array}{c}.334 \\
* *\end{array}$ & $\begin{array}{c}.426 \\
* *\end{array}$ & $\begin{array}{c}.376 \\
* *\end{array}$ & 1 & & \\
\hline (15) & $\begin{array}{c}- \\
.135\end{array}$ & $\begin{array}{c}- \\
.173 \\
*\end{array}$ & $\begin{array}{c}- \\
.085\end{array}$ & $\begin{array}{c}- \\
.106\end{array}$ & $\begin{array}{c}.158 \\
*\end{array}$ & $\begin{array}{c}- \\
.110\end{array}$ & $\begin{array}{c}- \\
.133\end{array}$ & $\begin{array}{c}- \\
.092\end{array}$ & $\begin{array}{c}- \\
.036\end{array}$ & $\begin{array}{c}.258 \\
* *\end{array}$ & $\begin{array}{c}.254 \\
* *\end{array}$ & $\begin{array}{c}.323 \\
* *\end{array}$ & $\begin{array}{c}.332 \\
* *\end{array}$ & $\begin{array}{c}.602 \\
* *\end{array}$ & 1 & \\
\hline (16) & $\begin{array}{c}.503 \\
* *\end{array}$ & $\begin{array}{c}.390 \\
* *\end{array}$ & $\begin{array}{c}.460 \\
* *\end{array}$ & $\begin{array}{c}.435 \\
* *\end{array}$ & $\begin{array}{c}- \\
.233 \\
* *\end{array}$ & $\begin{array}{c}.431 \\
* *\end{array}$ & $\begin{array}{c}.723 \\
* *\end{array}$ & .132 & $\begin{array}{c}.391 \\
* *\end{array}$ & $\begin{array}{c}- \\
410 \\
. *\end{array}$ & $\begin{array}{c}- \\
.371 \\
* *\end{array}$ & $\begin{array}{c}- \\
.225 \\
* *\end{array}$ & $\begin{array}{c}- \\
.398 \\
* *\end{array}$ & $\begin{array}{c}- \\
.235 \\
* *\end{array}$ & $\begin{array}{c}- \\
.19 \\
8^{*}\end{array}$ & 1 \\
\hline
\end{tabular}

(1): Well-being 1 (2): Well-being 2 (3): flourishing, (4): + affect, (5): - affect, (6): life satisfaction (7): job satisfaction, (8): general health, (9): uplifting, (10): hassle, (11): depression, (12): anxiety, (13): job stress, (14): outside work stress 1, (15) outside work stress 2, (16) Psychological Contract

$* \mathrm{p}<.05 \quad * * \mathrm{p}<0.01$

\subsection{The Relationship Between Job characteristics, Psychological Contract Fulfilment, Job Attitudes and Work Behaviours}

The next analysis examined associations between Psychological Contract Fulfilment and job attitudes and work behaviours. Psychological Contract Fulfilment was positively correlated with affective commitment, employment relations, work motivation, work effort, altruism, courtesy, conscientiousness, sportsmanship and civic value (see Table 10). It was negatively correlated with job insecurity and intention to quit. Job demands were positively associated with job insecurity and intention to quit (see Table 11). In contrast, they were negatively correlated with employment relations, courtesy and sportsmanship. Job control was positively correlated with affective commitment, employment relations, motivation, effort, altruism, courtesy, conscientiousness, sportsmanship and civic virtue. However, control was negatively correlated with job insecurity and intention to quit. Most negative job characteristics showed a similar profile to job demands and most positive characteristics showed the same pattern of associations as control. The number of significant correlations varied slightly depending on the specific characteristic. For example, bullying was associated with more significant correlations than job demands and rewards were associated with more significant associations than control. 
Table 10. The Relationship between Psychological Contract Fulfilment, Job Attitudes and Work

Behaviours

\begin{tabular}{|c|c|c|c|c|c|c|c|c|c|c|c|c|}
\hline Variable & (1) & (2) & (3) & (4) & (5) & (6) & (7) & (8) & (9) & (10) & (11) & (12) \\
\hline (1) & 1 & & & & & & & & & & & \\
\hline (2) & $.447 * *$ & 1 & & & & & & & & & & \\
\hline (3) & $\begin{array}{l}- \\
.293 * *\end{array}$ & $-.365 * *$ & 1 & & & & & & & & & \\
\hline (4) & $.523^{* *}$ & $.416^{* * *}$ & $\begin{array}{l}- \\
.256 * *\end{array}$ & 1 & & & & & & & & \\
\hline (5) & $.586^{* * *}$ & $.474^{* *}$ & $\begin{array}{l}.293^{* *}\end{array}$ & $.816^{* * *}$ & 1 & & & & & & & \\
\hline (6) & $.237 * *$ & $.189^{*}$ & -.152 & $.478 * *$ & $.419 * *$ & 1 & & & & & & \\
\hline (7) & $.465^{* *}$ & $.247 * *$ & $\begin{array}{l}- \\
.230^{* *}\end{array}$ & $.467 * *$ & $.428 * *$ & $.623 * *$ & 1 & & & & & \\
\hline (8) & $.183^{*}$ & .137 & $\begin{array}{l}- \\
.234 * *\end{array}$ & $.465 * *$ & $.396 * *$ & $.529 * *$ & $.556^{* *}$ & 1 & & & & \\
\hline (9) & $.332 * *$ & $.163^{*}$ & $-.163^{*}$ & $.558 * *$ & $.478 * *$ & $.527 * *$ & $.623 * *$ & $.711 * *$ & 1 & & & \\
\hline (10) & $.244 * *$ & $.248 * *$ & $-.167 *$ & $.576^{* *}$ & $.493 * *$ & $.478 * *$ & $.511 * *$ & $.677 * *$ & $.711 * *$ & 1 & & \\
\hline (11) & $.396^{* *}$ & $.291 * *$ & -.133 & $.577 * *$ & $.508 * *$ & $.443 * *$ & $.544 * *$ & $.578 * *$ & $.690^{* * *}$ & $.706^{* *}$ & 1 & \\
\hline (12) & $\begin{array}{l}-.147 \\
\end{array}$ & -.455 & $.484 * *$ & -.469 & -.472 & $\begin{array}{l}-.132 \\
\end{array}$ & -.145 & $-.174 *$ & $\begin{array}{l}- \\
.232 * *\end{array}$ & $\begin{array}{l}- \\
.292 * *\end{array}$ & $\begin{array}{l}- \\
.225 * *\end{array}$ & 1 \\
\hline (13) & $.514 * *$ & $.591 * *$ & $\begin{array}{l}. \\
.473^{* *}\end{array}$ & $.612 * *$ & $.583 * *$ & $.361 * *$ & $.251 * *$ & $.367 * *$ & $.323 * *$ & $.453^{* *}$ & $.414 * *$ & $-.555 * *$ \\
\hline
\end{tabular}

(1): affective commitment, (2): employment relations, (3): work security, (4): work motivation 1, (5): work motivation 2,

(6): work effort, (7): altruism, (8): courtesy,

(9): conscientiousness, (10): sportsmanship, (11): civic virtue, (12): intention to quit, (13): psychological contract.

$* \mathrm{p}<.05$

$* * \mathrm{p}<0.01$ 
Table 11. The Relationship between Job Characteristics (Work Demands \& Work Resources) and Job Attitudes \& Work Behaviour

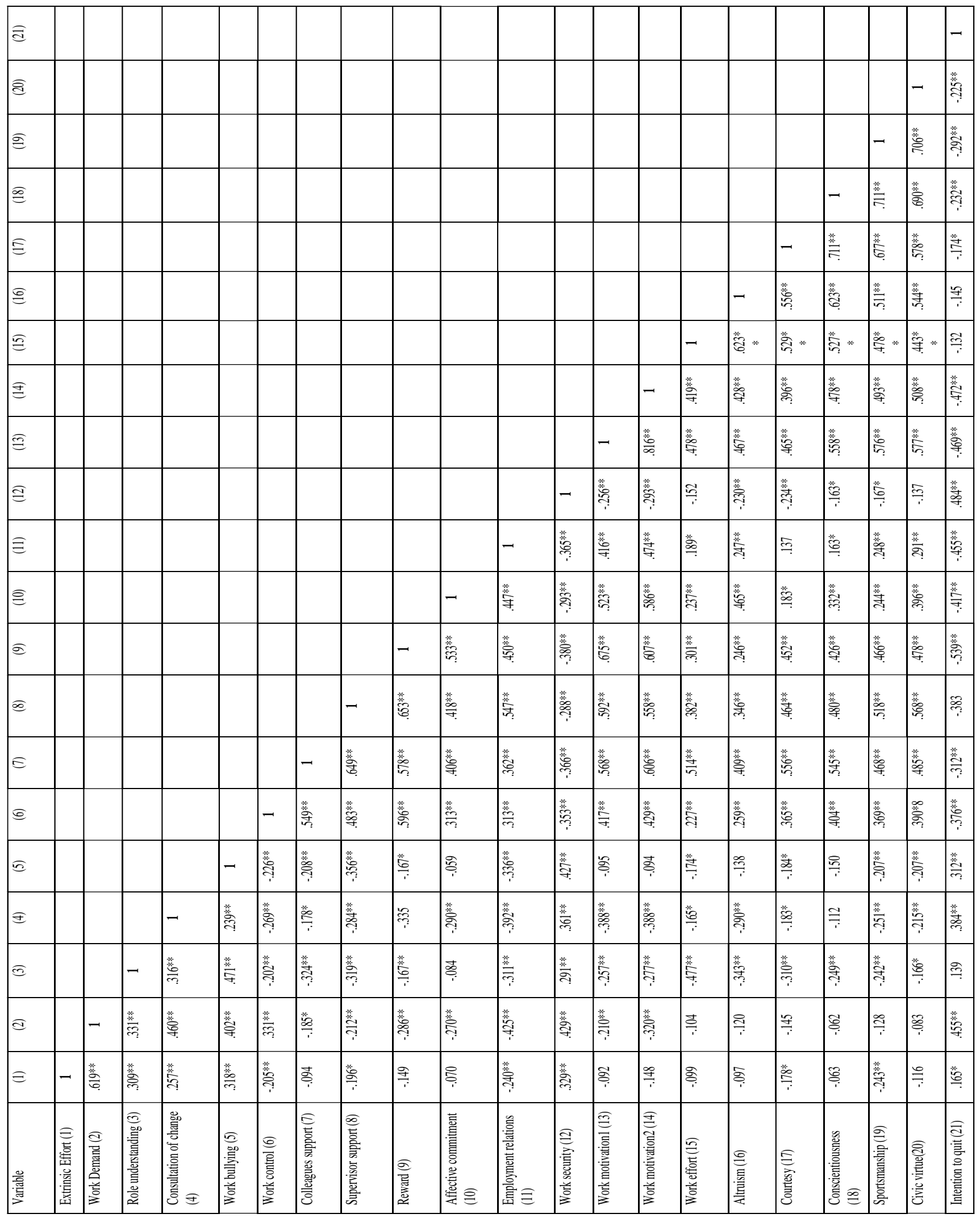

$* \mathrm{p}<.05 \quad * * \mathrm{p}<0.01$ 


\section{DISCUSSION}

The general aim of the research described in this article was to integrate research on Psychological Contract Fulfilment and well-being. Two models were used to achieve this. The first, the Guest (1989) model, considers background factors such as characteristics of the organisation and individual, and then describes the state of Psychological Contract Fulfilment in terms of Fairness, Trust and the "Delivery of the Deal". There are then attitudinal consequences of PCF namely organisational commitment, job satisfaction, employment relations, work-life balance and job security. The behavioural consequences include increased motivation, organisational citizenship and increased intention to stay in the job. The DRIVE model (Mark and Smith, 2008) was used to conceptualise the well-being process. This model includes job demands, job resources (control and support), individual differences (coping and personality), job appraisals (perceived stress and job satisfaction) and positive and negative outcomes (positive and negative affect).

In order to include all of these factors in a survey it is necessary to develop short versions of the different concepts. This has already been done for the DRIVE model and led to the development of the WPQ and SWELL measuring instruments. The first objective of the present research was to do this for the consequences of PCF. Short items measuring aspects of attitudinal and behavioural consequences were constructed and validated by examining correlations with the original longer scales from which they were developed. The results showed high correlations (often in the range of 0.7-0.8) between the new short items and the longer versions.

The next step in the analysis examined associations between job characteristics, PCF and the attitudinal and behavioural consequences. Psychological Contract Fulfilment was negatively correlated with demands and other negative job characteristics and was positively correlated with control, support and rewards (resources). With regards to individual differences, PCF was negatively correlated with avoidance coping and was positively correlated with the Big 5 dimensions (openness; conscientiousness; extraversion; agreeableness; and emotional stability) and the positive personality dimensions of self-esteem, self-efficacy, and optimism. In terms of well-being outcomes, Psychological Contract Fulfilment was positively correlated with well-being both at work (e.g. job satisfaction) and in life generally (e.g. positive affect; life satisfaction). In contrast, it was negatively correlated with low well-being scores both at work (e.g. job stress) and in life generally (e.g. negative affect; stress outside of work; anxiety and depression). These findings provide support for an integrated PCF/DRIVE model.

The final analyses examined associations between short measures of job characteristics, Psychological Contract Fulfilment and job attitudes and work behaviours. Job demands were positively associated with intention to quit and job insecurity. However, demands were negatively correlated with 
employment relations, courtesy and sportsmanship. Job control was positively correlated with affective commitment, employment relations, motivation, effort, altruism, courtesy, conscientiousness, sportsmanship and civic virtue. In contrast, control was negatively correlated with job insecurity and intention to quit. Most negative job characteristics showed a similar profile to job demands and most positive characteristics showed the same pattern of associations as control. The number of significant correlations depended on the specific characteristic being considered. For example, bullying was associated with more significant correlations than job demands and rewards were associated with more significant associations than control. Psychological Contract Fulfilment was positively correlated with affective commitment, employment relations, work motivation, work effort, altruism, courtesy, conscientiousness, sportsmanship and civic value. It was negatively correlated with job insecurity and intention to quit. Overall, these associations provide further support for the PCF/DRIVE model.

The present study was intended to form the basis for further research by developing short measuring instruments and integrating models of PCF and well-being. Further research is now required to extend the present approach. For example, it is now important to conduct multi-variate analyses to determine whether PCF, attitudinal and behavioural consequences influence well-being when organisational and individual factors are controlled. It is also difficult to define the causal pathways from the present study because of the cross-sectional design. Future research should use a longitudinal design, preferably with interventions aimed at increasing PCF and the consequences of it. It is also important to determine whether the present results generalise to other samples of workers in different countries. 


\section{REFERENCES}

Argyris, C. (1960). Understanding Organisational Behaviour. Homewood, IL: Dorsey Press.

Bal, M. P., De Cooman, R., \& Mol, T. S. (2003). Dynamics of psychological contracts with work engagement and turnover intention: The influence of organizational tenure. European Journal of Work and Organisational Psychology, 22(1), 107-122. doi: 10.1080/1359432X.2011.626198

Bandura, A. (1988). Self-efficacy conception of anxiety. Anxiety research, 1(2), 77-98. doi: 10.1080/10615808808248222

Bandura, A., \& Cervone, D. (1986). Differential engagement of self-reactive influences in cognitive motivation. Organizational Behavior and Human Decision Processes, 38(1), 92-113. doi: 10.1016/0749-5978(86)90028-2

Bateman, T. S., \& Organ, D. W. (1983). Job satisfaction and the good soldier: The relationship between affect and employee "citizenship." Academy of Management Journal, 26, 587-595. doi: 10.2307/255908

Bell, A. S., Rajendran, D., \& Theiler, S. (2012). Job stress, wellbeing, work-life balance and work-life conflict among Australian academics. E-Journal of Applied Psychology, 8(1), 25-37. doi: 10.7790/ejap.v8i1.320

Bjorklund, C., Jensen, I., \& Lohela-Karlsson, M. (2013). Is a change in work motivation related to a change in mental wellbeing? Journal of Vocational Behavior, 83(3), 571-580. doi: 10.1016/j.jvb.2013.09.002

Black, C. M. (2008). Working for a healthier tomorrow: Dame Carol Black's review of the health of Britain's working age population. London, UK: The Stationery Office.

Blau, P. (1964). Exchange and power in social life. New York: John Wiley \& Sons.

Borman, W. C., Buck, D. E., Hanson, M. A., Motowidlo, S. J., Stark, S., \& Drasgow, F. (2001). An examination of the comparative reliability, validity, and accuracy of performance ratings made using computerized adaptive rating scales. Journal of Applied Psychology, 86, 965-973. doi: 10.1037//0021-9010.86.5.965

Boyd, N. M., \& Nowell, B. (2017). Testing a theory of sense of community and community responsibility in organizations: an empirical assessment of predictive capacity on employee wellbeing and organisational citizenship. Journal of Community Psychology, 45(2), 210-229. doi: 10.1002/jcop.21843

Burke, R. J., Oberklaid, F., \& Burgess, Z. (2003). Organizational values, work experiences, and satisfactions among Australian psychologists. The International Journal of Organizational Analysis, 11(2), 123-135. doi: 10.1108/eb028966

Cassidy, T. \& Lynn, R. (1989). A multifactoral approach to achievement motivation: The development of a comprehensive measure. Journal of Occupational Psychology, 62, 301-312.

Coetzee, S. E., \& Rothmann, S. (2005). Occupational stress, organisational commitment and ill-health of employeesat a higher education institution in South Africa. SA Journal of Industrial Psychology, 31(1), 47-54. doi: 10.4102/sajip.v31i1.179

Conway, N., \& Briner, R. B. (2002). Full-time versus part-time employees: Understanding the links between work status, the psychological contract, and attitudes. Journal of Vocational Behavior, 61(2), 279-301. doi: 10.1006/jvbe.2001.1857

Costa, P. T., \& McCrae, R. R. (1980). Influence of extraversion and neuroticism on subjective well-being: Happy and unhappy people. Journal of Personality and Social Psychology, 38(4), 668-678. doi: 10.1037//00223514.38.4.668

Coyle-Shapiro, J. A. M., \& Parzefall, M. (2008). Psychological contracts. In: C. L. Cooper \& J. Barling (Eds.), The Sage Handbook of Organizational Behavior (pp. 70-80). London, UK: SAGE Publications.

Dabos, G. E., \& Rousseau, D. M. (2004). Mutuality and reciprocity in the psychological contract of employees and employers. Journal of Applied Psychology, 89(1), 52-72. doi: 10.1037/0021-9010.89.1.52

Dasgupta, S. (2001). Employment security: Conceptual and statistical issues. Vol. 10. Geneva: International Labour Office.

Dávila, M. C., \& Finkelstein, M. A. (2013). Organizational citizenship behavior and well-being: Preliminary results. International Journal of Applied Psychology, 3(3), 45-51. doi: 10.5923/j.ijap.20130303.03

De Cooman, R., De Gieter, S., Pepermans, R., Jegers, M., \& Van Acker, F. (2009). Development and validation of the work effort scale. European Journal of Psychological Assessment, 25(4), 266-273. doi: 10.1027/10155759.25.4.266

Deci, E. L., Koestner, R., \& Ryan, R. M. (1999). A meta-analytic review of experiments examining the effects of extrinsic rewards on intrinsic motivation. Psychological Bulletin, 125(6), 627-668. doi: 10.1037//0033-2909.125.6.627

De Cuyper, N., Bernhard-Oettel, C., Berntson, E., De Witte, H., \& Alarco, B. (2008). Employability and employees' wellbeing: Mediation by job insecurity. Applied Psychology: An International Review, 57(3), 488-509. doi: 10.1111/j.1464-0597.2008.00332.x

De Cuyper, N., \& De Witte, H. (2006). The impact of job insecurity and contract type on attitudes, well-being and behavioural reports: a psychological contract perspective. Journal of Occupational and Organizational Psychology, 79(3), 395-409. doi: 10.1348/096317905x53660

De Cuyper, N., \& De Witte, H. (2007). Job insecurity in temporary versus permanent workers: Associations with attitudes, well-being, and behaviour. Work \& Stress, 21(1), 65-84. doi: 10.1080/02678370701229050 
De Cuyper, N., Van der Heijden, B. I., \& De Witte, H. (2011). Associations between perceived employability, employee well-being, and its contribution to organizational success: a matter of psychological contracts?. The International Journal of Human Resource Management, 22(7), 1486-1503. doi: 10.1080/09585192.2011.561962

Demerouti, E., Bakker, A. B., \& Sanz-Vergel, A. I. (2013). Recovery and work-life interface. In: D. A. Major \& R. Burke [Eds.], Handbook of work-life integration among professionals: Challenges and opportunities (pp. 225-244). Northampton, MA: Edward Elgar Publishing. doi: 10.4337/9781781009291.00022

DeNeve, K. M., \& Cooper, H. (1998). The happy personality: a meta-analysis of 137 personality traits and subjective wellbeing. Psychological Bulletin, 124(2), 197-229. doi: 10.1037//0033-2909.124.2.197.

De Witte, H. (2000). Work ethic and job insecurity: Assessment and consequences for well-being, satisfaction and performance at work. In R. Bouwen, K. De Witte, H. De Witte \& T. Taillieu (Eds.), Van Groep tot Gemeenschap (From Group to Community) (pp. 325-350). Leuven, Belgium: Garant.

De Witte, H. (1999). Job insecurity and psychological well-being: Review of the literature and exploration of some unresolved issues. European Journal of Work and Organizational Psychology, 8(2), 155-177. doi: $10.1080 / 135943299398302$

De Witte, H., Pienaar, J., \& De Cuyper, N. (2016). Review of 30 years of longitudinal studies on the association between job insecurity and health and well-being: Is there causal evidence? Australian Psychologist, 51(1), 18-31. doi: 10.1111/ap.12176

De Witte, H., Vander Elst, T., \& De Cuyper, N. (2015). Job insecurity, health and well-being. In J. Vuori, R. Blonk, \& R. H. Price (Eds.), Aligning perspectives on health, safety and wellbeing. Sustainable working lives: Managing work transitions and health throughout the life course (pp. 109-128). New York, NY, US: Springer Science + Business Media; US. doi: 10.1007/978-94-017-9798-6_7

Diener, E. (1984). Subjective well-being. Psychological Bulletin, 93(3), 542-575. doi: 10.1037//0033-2909.95.3.542

Diener, E. (1996). Traits can be powerful, but are not enough: lessons from subjective well-being. Journal of Research in Personality, 30(3), 389-399. doi: 10.1006/jrpe.1996.0027

Diener, E., Oishi, S., \& Lucas, R. E. (2003). Personality, Culture, and Subjective Well-being: Emotional and Cognitive Evaluations of Life. Annual Review of Psychology, 54, 403-425. doi:10.1146/annurev.psych.54.101601.145056

Diener, E., Sapyta, J. J., \& Suh, E. (1998). Subjective Well-Being Is Essential to Well-Being. Psychological Inquiry, 9(1), 33-37. doi: 10.1207/s15327965pli0901_3

Diener, E., Suh, E. M., Lucas, R. E., \& Smith, H. L. (1999). Subjective well-being: Three decades of progress. Psychological Bulletin, 125(2), 276-302. doi: 10.1037//0033-2909.125.2.276

Feigon, M., Block, C., Guidotti Breting, L., Boxley, L., Dawson, E., \& Cobia, D. (2018). Work-life integration in neuropsychology: A review of the existing literature and preliminary recommendations. The Clinical Neuropsychologist, 32(2), 300-317. doi: 10.1080/13854046.2017.1411977

Fernet, C., \& Austin, S. (2014). Self-determination and job stress. In M. Gagne(Ed), The Oxford handbook of work engagement, motivation, and self-determination theory (pp. 231-244). New York, NY, US: Oxford University Press; US.

Folkman, S., \& Lazarus, R. S. (1980). An analysis of coping in a middle-aged community sample. Journal of Health and Social Behavior, 21(3), 219-239. doi: 10.2307/2136617.

Frone, M. R. (2003). Work-family balance. In J. C. Quick \& L. E. Tetrick (Eds.), Handbook of Occupational Health Psychology (pp. 143-162). Washington, DC: American Psychological Association.

Frone, M. R., Russell, M., \& Cooper, M. L. (1992). Antecedents and outcomes of work-family conflict: Testing a model of the work-family interface. Journal of Applied Psychology, 77, 65-78. doi: 10.1037//0021-9010.77.1.65

Gouldner, A, W. (1960). The norm of reciprocity. American Sociological review, 25(2), 161-178. doi: 10.2307/2092623

Grawitch, M. J., Barber, L. K., \& Justice, L. (2010). Rethinking the work-life interface: It's not about balance, it's about resource allocation. Applied Psychology: Health and Well-Being, 2(2), 127-159. doi: 10.1111/j.17580854.2009.01023.X

Grebner, S., Semmer, N. K., Lo Faso, L., Gut, S., Kalin, W., \& Elfering, A. (2003). Working conditions, well-being, and job-related attitudes among call centre agents. European Journal of Work and Organizational Psychology, 12(4), 341-365. doi: 10.1080/13594320344000192

Gottfried, A. E., Fleming, J. S, \& Gottfried, A. W. (2004). Continuity of academic intrinsic motivation from children through late adolescence: A longitudinal study. Journal of Educational Psychology, 93(1), 3-13. doi: 10.1037//0022-0663.93.1.3

Greenberg, J. (2011). Behavior in Organizations. (10th ed.). London, England: Pearson Education $\quad$ Ltd.

Gropel, P., \& Kuhl, J. (2009). Work-life balance and subjective well-being: The mediating role of need fulfilment. British Journal of Psychology, 100(2), 365-375. doi: 10.1348/000712608x337797

Guay, F., Chanal, J., Ratelle, C. F., Marsh, H. W., Larose, S., \& Boivin, M. (2010). Intrinsic, identified, and controlled types of motivation for school subjects in young elementary school children. British Journal of Educational Psychology, 80(4), 711-735. doi: 10.1348/000709910x499084

Guest, D. E. (1989). "Is the psychological contract worth taking seriously?". Journal of Organisational Behaviour, 19(1), 649-664. doi: 10.1002/(sici)1099-1379(1998)19:1+<649::aid-job970>3.0.co;2-t 
Guest, D., \& Conway, R. (2002). Communicating the psychological contract: An employer perspective. Human Resource Management Journal, 12(2), 22-38. doi: 10.1111/j.1748-8583.2002.tb00062.x

Haider, S., Jabeen, S., \& Ahmad, J. (2018). Moderated mediation between work life balance and employee job performance: The role of psychological wellbeing and satisfaction with coworkers. Journal of Work and Organizational Psychology, 34(1), 29-37. doi: 10.5093/jwop2018a4

Haar, J. M., Russo, M., Sune, A., \& Ollier-Malaterre, A. (2014). Outcomes of work-life balance on job satisfaction, life satisfaction and mental health: A study across seven cultures. Journal of Vocational Behavior, 85(3), 361-373. doi: 10.1016/j.jvb.2014.08.010

Hayes, N., \& Joseph, S. (2003). Big 5 correlates of three measures of subjective well-being. Personality and Individual Differences, 34(4), 723-727. doi: 10.1016/s0191-8869(02)00057-0

Hill, E. J., Hawkins, A. J., Ferris, M., \& Weitzman, M. (2001). Finding an extra day a week: The positive influence of perceived job flexibility on work and family life balance. Family Relations, 50, 49-58.

Headey, B., \& Wearing, A. (1989). Personality, Life Events, and Subjective Well-Being: Toward a Dynamic Equilibrium Model. Journal of Personality and Social Psychology, 57(4), 731-739. doi: 10.1037//0022-3514.57.4.731

Ilgen, D. R., \& Klein, H. J. (1989). Organizational behavior. In M.R. Rosenzweig \& L.W. Porter (Eds.), Annual Review of Psychology (Vol. 40, pp. 327-51). Palo Alto, CA: Annual Reviews.

ILO. (1995). Labour Market Indicators Questionnaire 1995 (Geneva, EMPFORM, ILO)

Isaksson, K., Bernhard, C., Claes, R., De White, H., Guest. D., Krausz, M., Mohr, G., Peiro, M. J., \& Schalk, R. (2003). Employment contracts and psychological contract in Europe: Result from a pilot study. Saltsa Report, 2003(i), 138.

Johnson, J. V., \& Hall, E. M. (1988). Job strain, workplace social support, and cardiovascular disease. A cross-sectional study of random sample of the Swedish working population. America Journal of Public Health, 78(10), 13361342. doi: 10.2105/ajph.78.10.1336

Judge, T. A., Erez, A., Bono, J. E., \& Thoresen, C. J. (2002). Are measures of self-esteem, neuroticism, locus of control, and generalized self-efficacy indicators of a common core construct? Journal of Personality and Social Psychology, 83(3), 693-710. doi: 10.1037//0022-3514.83.3.693

Kinman, G., \& Jones, F. (2008). A life beyond work? Job demands, work-life balance, and wellbeing in UK academics. Journal of Human Behavior in the Social Environment, 17(1-2), 41-60. doi: 10.1080/10911350802165478

Kluemper, D. H., Little, L. M., \& DeGroot, T. (2009). State or trait: effects of state optimism on job-related outcomes. Journal of organizational Behavior, 30(2), 209-231. doi: 10.1002/job.591

Knapp, M., McDaid, D., Mossialos, E., \& Thornicroft, G. (2006). Mental health policy and practice across Europe. Maidenhead: Open University Press.

Kompier, M. A. J., Taris, T. W., \& van Veldhoven, M. (2012). Tossing and turning-Insomnia in relation to occupational stress, rumination, fatigue, and well-being. Scandinavian Journal of Work, Environment \& Health, 38(3), 238246. doi: $10.5271 /$ sjweh.3263

Kumar, M., Jauhari, H., \& Singh, S. (2016). Organizational citizenship behavior \& employee well-being. Indian Journal of Industrial Relations, 51(4), 594-608.

Kuvaas, B. (2006). Performance appraisal satisfaction and employee outcomes: mediating and moderating roles of work motivation. The International Journal of Human Resource Management, 17(3), 504-522. doi: $10.1080 / 09585190500521581$

Lee, K., \& Allen, N. J. (2002). Organizational citizenship behavior and workplace deviance: The role of affect and cognitions. Journal of Applied Psychology, 87(1), 131-142. doi: 10.1037//0021-9010.87.1.131

Lee-Flynn, S. C., Pomaki, G., DeLongis, A., Biesanz, J. C., \& Puterman, E. (2011). Daily cognitive appraisals, daily affect, and long-term depressive symptoms: The role of self-esteem and self-concept clarity in the stress process. Personality and Social Psychology Bulletin, 37(2), 255-268. doi: 10.1177/0146167210394204

Levinson, H., Proce, C. R., Munden, K. J., Mandl, H. J. Solley, C. M. (1962). Men, Management and Mental Health. Boston: Harvard University Press.

MacKenzie, S. B., Podsakoff, P. M., \& Fetter, R. (1993). The impact of organizational citizenship behavior on evaluations of sales performance. Journal of Marketing, 57(1), 70-80. doi: 10.2307/1252058

Mark, G. M., \& Smith, A. P. (2008). Stress models: A review and suggested new direction. In J. Houdmont \& S. Leka (Eds.), Occupational Health Psychology: European Perspectives on Research, Education and Practice (Vol. 3, pp. 111-144). Nottingham: Nottingham University Press.

Mark, G., \& Smith, A. P. (2012a). Effects of occupational stress, job characteristics, coping, and attributional style on the mental health and job satisfaction of university employees. Anxiety, Stress \& Coping, 25(1), 63-78. doi: 10.1080/10615806.2010.548088

Mark, G., \& Smith, A. P. (2012b). Occupational stress, job characteristics, coping, and the mental health of nurses. British Journal of Health Psychology, 17(3), 505-521. doi: 10.1111/j.2044-8287.2011.02051.x

Marks, A. (2001). "Developing a multiple foci conceptualization of the psychological contract". Employee Relations, 23(5), 454 - 469. doi: 10.1108/eum0000000005897 
Maydeu-Olivares, A., Kramp, U., García-Forero, C., Gallardo-Pujol, D., \& Coffman, D. (2009). The Effect of Varying the Number of Response Alternatives in Rating Scales: Experimental Evidence from Intra-Individual Effects. Behavior Research Methods, 41, 295-308. https://doi.org/10.3758/BRM.41.2.295

Meyer, J \& Allen, N. (1997). Commitment in the Workplace: Theory, Research, and Application. Thousand Oaks, CA: SAGE Publications.

Meyer, J. P., \& Allen, N. J. (1991). A three component conceptualization of organizational commitment. Human Resource Management Review, 1(1), 61-89. doi: 10.1016/1053-4822(91)90011-z

Millward, L. J., \& Hopkins, L. J. (1998). Psychological contracts, organizational and job commitment. Journal of Applied Social Psychology, 28(16), 1530-56. doi: 10.1111/j.1559-1816.1998.tb01689.x

Mowday, R. T., Koberg, C. S., \& McArthur, A. W. (1984). The psychology of withdrawal process: A cross-validation test of Mobley's intermediate linkages model of turnover in two samples. Academy of Management Journal, 27(1), 79-94. doi: $10.2307 / 255958$

Naylor, J.C., Pritchard, R.D., \& Ilgen, D.R. (1980). A theory of behavior in organizations. New York: Academic Press.

Netemeyer, R. G., Boles, J.S., \& McMurrian, R. (1996). Development and validation of work-family conflict and familywork conflict scales. Journal of Applied Psychology, 81(4), 400-410. doi: 10.1037/0021-9010.81.4.400

Ng, E., Hong, C., Hao, L. Z., Kumar, R., Ramendran, C., \& Kadiresan, V. (2012). An effectiveness of human resource management practices on employee retention in institute of higher learning: A regression analysis. International Journal of Business Research and Management, 3(2), 60-79.

Nikolaou, I., \& Tsaousis, I. (2002). Emotional intelligence in the workplace: Exploring its effects on occupational stress and organizational commitment. The International Journal of Organizational Analysis, 10(4), 327-342. doi: $10.1108 / \mathrm{eb028956}$

Organ, D. W. (1988). Organizational citizenship behaviour: The good soldier syndrome. Lexington, MA: Lexington Books.

Organ, D. W. (1990). The subtle significance of job satisfaction. Clinical Laboratory Management Review, 4(1), 94-98.

Organ, D. W. (1997). Organizational citizenship behaviour: It's construct clean-up time. Human Performance, 10(2), 8597. doi: 10.1207/s15327043hup1002_2

Panaccio, A., \& Vandenberghe, C. (2009). Perceived organizational support, organizational commitment and psychological well-being: A longitudinal study. Journal of Vocational Behavior, 75(2), 224-236. doi: 10.1016/j.jvb.2009.06.002

Parkinson, J. (2007). Review of scales of positive mental health validated for use with adults in the UK: Technical report. Health Scotland, Edinburgh, Scotland.

Pavot, W., \& Diener, E. (1993). The affective and cognitive context of self-reported measures of subjective well-being. Social Indicators Research, 28(1), 1-20. doi: 10.1007/bf01086714

Peterson, C. (1991). On shortening the Expanded Attributional Style Questionnaire. Journal of Personality Assessment, 56(1), 179-183. doi: 10.1207/s15327752jpa5601_16

Podsakoff, P. M., MacKenzie, S. B., Moorman, R. H., \& Fetter, K. (1990). Transformational leader behaviours and their effects on followers' trust in leader, satisfaction, and organizational citizenship behaviours. The Leadership Quarterly, 1(2), 107-142. doi: 10.1016/1048-9843(90)90009-7

Podsakoff, P. M., MacKenzie, S. B., Paine, J. B., \& Bachrach, D. G. (2000). Organizational citizenship behaviours: A critical review of the theoretical and empirical literature and suggestions for future research. Journal of Management, 26(3), 513-563. doi: 10.1177/014920630002600307

Quick, J. D., Henley, A. B., \& Quick, J. C. (2004). The balancing act: At work and at home. Organizational Dynamics, 33(4), 426-438. doi: 10.1016/j.orgdyn.2004.09.008

Quine, L. (1999). Workplace bullying in NHS community trust: Staff questionnaire survey. British Medical Journal, 318(7178), 228-232. doi: 10.1136/bmj.318.7178.228.

Reeve, J. (2009). Understanding motivation and emotion (5th Ed.). Hoboken, NJ: John Wiley \& Son, Inc.

Reiter, N. (2007). Work life balance: What do you mean? The ethical ideology underpinning appropriate application. Journal of Applied Behavioral Science, 43(2), 273-294. doi: 10.1177/0021886306295639

Rick, J., Briner, R. B., Daniels, K., Perryman, S., \& Guppy, A. (2001). A critical review of psychosocial hazard measures. HSE Books, HMSO, Norwich.

Robinson, S. L., Kraatz, M., \& Rousseau, D. M. (1994). Changing obligations and the psychological contract: A longitudinal study. Academy of Management Journal, 37(1), 137-152. doi: 10.2307/256773

Rousseau, D. M. (1989). Psychological and implied contract in organisations. Employee Responsibilities and Rights Journal, 2(2), 121-139. doi: 10.1007/bf01384942

Rousseau, D. M. (1995). Psychological contract in organisations: Understanding written and unwritten agreements. Thousand Oaks, CA: Sage.

Rousseau, D. M. (2011). The individual-organisation relationship: The psychological contract. In S. Zedecj (Ed.), APA of handbook of industrial and organisational psychology (pp. 191-220). Washington, DC: American Psychological Association.

Sackett, P. R., \& Larson Jr., J. R. (1990). Research Strategies and Tactics in Industrial and Organizational Psychology. In M. D. Dunnett, \& L. M. Hough (Eds.), Handbook ofIndustrial and Organizational Psychology (2nd ed., Vol. 1, pp. 419-489). Palo Alto, CA:Consulting Psychologists Press. 
Saucan, D. S., Marhan, A. M.,\& Micle, M. I. (2014). Intention to quit job-Consequence of work-family conflict. A Romanian pilot study. Revista de Psihologie, 60(3), 253-259.

Schaufeli, W. B. (2016). Job insecurity research is still alive and kicking twenty years later: A commentary. Australian Psychologist, 51(1), 32-35. doi: 10.1111/ap.12201

Scheier, M. F., Carver, C. S., \& Bridges, M. W. (1994). Distinguishing Optimism from Neuroticism (and Trait Anxiety, Self-Mastery, and Self-Esteem): A Reevaluation of the Life Orientation Test. Journal of Personality and Social Psychology, 67(6), 1063-1078. doi: 10.1037//0022-3514.67.6.1063

Schein, E. H. (1965). Organisational Psychology. Englewood Cliffs, NJ: Prentice Hall.

Schimmack, U., Oishi, S., Furr, R. M., \& Funder, D. C. (2004). Personality and life satisfaction: A facet-level analysis. Personality and Social Psychology Bulletin, 30(8), 1062-1075.

Sharpe, J. P., Martin, N. R., \& Roth, K. A. (2011). Optimism and the Big Five factors of personality: Beyond neuroticism and extraversion. Personality and Individual Differences, 51(8), 946-951. doi: 10.1016/j.paid.2011.07.033

Siegrist, J. (1996). Adverse health effects and high effort/ low reward conditions. Journal of Occupational Health Psychology, 1(1), 27-41. doi: 10.1037//1076-8998.1.1.27

Silla, I., De Cuyper, N., Gracia, F. J., Peiro, J. M., \& De Witte, H. (2009). Job insecurity and well-being: Moderation by employability. Journal of Happiness Studies, 10(6), 739-751. doi: 10.1007/s10902-008-9119-0

Siu, O. L. (2002). Occupational stressors and well-being among Chinese employees: The role of organisational commitment. Applied Psychology, 51(4), 527-544. doi: 10.1111/1464-0597.t01-1-00106

Siu, O. L. (2013). Psychological capital, work well-being, and work-life balance among Chinese employees: A crosslagged analysis. Journal of Personnel Psychology, 12(4), 170-181. doi: 10.1027/1866-5888/a000092

Smith, A. P., McNamara, R. L., \& Wellens, B. T. (2004). Combined Effects of Occupational Health Hazards (Report 287). HSE Contract Research. HSE Books.

Smith, A., Johal, S., \& Wadsworth, E. (2000). The Scale of Occupational Stress: The Bristol Stress and Health at Work Study. Contract Research Report 265/2000, Sudbury: HSE Books.

Smith, A., Wadsworth, E., Chaplin, K., Allen, P., \& Mark, G. (2009). What is a good job? The relationship between work/working and improved health and well-being. Wigston, UK: IOSH.

Sonnentag, S., \& Frese, M. (2013). Stress in organisation. In W. C. Borman, D. R. Ilgen, \& R. J. Klimoski (Eds.), Comprehensive Handbook of Psychology: Industrial and Organisational Psychology (Vol. 12, pp. 453-491). Hoboken, NJ: John Wiley and Sons.

Steel, P., Schmidt, J., \& Shultz, J. (2008). Refining the Relationship between Personality and Subjective Well-Being. Psychological Bulletin, 134(1), 138-161. doi: 10.1037/0033-2909.134.1.138

Steers, R. M. (1977). Antecedents and Outcomes of Organizational Commitment. Administrative Science Quarterly, 22(1), 46-56. doi: 10.2307/2391745

Stiglbauer, B., Selenko, E., Batinic, B., \& Jodlbauer, S. (2012). On the link between job insecurity and turnover intentions: Moderated mediation by work involvement and well-being. Journal of Occupational Health Psychology. 17(3), 354-364. doi: 10.1037/a0028565

Tambe, S., \& Shanker, M. (2014). A study of organisational citizenship behaviour and its dimensions: A literature review. International Research Journal of Business and Management, 1, 67-73.

Taylor, M. S., \& Tekleab, A. G. (2004). Taking stock of psychological contract research: Assessing progress, addressing troublesome issues and setting research priorities. In J. A. M. Coyle-Shapiro, L. M. Shore, M. S. Taylor, \& L. E. Tetrick, (Eds.)The employment relationship: Examining psychological and contextual perspectives (pp. 253-283). Oxford: Oxford University Press.

Tsutsumi, A., \& Kawakami, N. (2004). A review of empirical studies on the model of effort-reward imbalance at work: reducing occupational stress by implementing a new theory. Social science \& medicine, 59(11), 2335-2359. doi: 10.1016/j.socscimed.2004.03.030

Turnipseed, D. \& Rasuli, A. (2005). Performance perceptions of organizational citizenship behavior at work. British Journal of Management, 163, 23-29.

Turnley, W. H., Bolino, M. C., Lester, S. W., \& Bloodgood, J. M. (2003). The impact of psychological contract fulfilment on the performance of in-role and organizational citizenship behaviors. Journal of Management, 29(2), 187-206. doi: $10.1177 / 014920630302900204$

Van Der Doef, M., \& Maes, S. (1999). The Job Demand-Control (-Support) model and psychological well-being: A review of 20 years of empirical research. Work and Stress, 13(2), 87-114. doi: 10.1080/026783799296084

Waldron, S. (2010). Measuring subjective wellbeing in the UK. Newport: Office for National Statistics.

Wegge, J., Van Dick, R., Fisher, G. K., Wecking, C., \& Moltzen, K. (2006). Work motivation, organizational identification, and well-being in call centre work. Work \& Stress, 20(1), 60-83. doi: $10.1080 / 02678370600655553$

Weisberg, J. (1994). Measuring workers' burnout and intention to leave. International Journal of Manpower, 15(1), 4-14. doi: $10.1108 / 01437729410053590$

Williams G.M (2015) Researching and developing mental health and wellbeing assessment tools for supporting employees and employers in Wales. http://orca.cf.ac.uk/71443/1/2015williamsphd.pdf 
Williams, G.M. \& Smith, A.P. (2012). A holistic approach to stress and well-being. Part 6: The Wellbeing Process Questionnaire (WPQ Short Form). Occupational Health (At Work), 9(1), 29-31.

Williams, G., Pendlebury, H., Thomas, K \& Smith, A.P. 2017. The student wellbeing process questionnaire (Student WPQ). Psychology, 8, 1748-1761 http://doi.org/10.4236/psych.2017.811115

Williams, G., Pendlebury, H. \& Smith, A.P. 2017. Stress and Well-being of Nurses: an Investigation using the DemandsResources- Individual Effects (DRIVE) model and Well-being Process Questionnaire (WPQ). Jacobs Journal of Depression and Anxiety, 1, 1-8. http://depressionandanxiety.jacobspublishers.com/images/Depression/J_J_Depr_Anxi_1_1_001.pdf

Williams, G., Thomas, K \& Smith, A.P. 2017. Stress and Well-being of University Staff: an Investigation using the Demands-Resources- Individual Effects (DRIVE) model and Well-being Process Questionnaire (WPQ). Psychology, 8, 1919-1940. https://doi.org/10.4236/psych.2017.812124

Williams, G.M. \& Smith, A.P. 2018a. A practical method of predicting wellbeing at work: the Wellbeing Process Tool. Advances in Social Sciences Research Journal, 5(2), 86-93. doi: 10.14738/assrj.52.4158. http://scholarpublishing.org/index.php/ASSRJ/article/view/4158/2506

Williams, G.M. \& Smith, A.P. 2018b. A longitudinal study of the well-being of students using the student well-being questionnaire (WPQ). Journal of Education, Society and Behavioral Science, 24(4), 1-6. doi:10.9734/JESBS/2018/40105

Williams, G.M. \& Smith, A.P. 2018c. Diagnostic validity of the anxiety and depression questions from the Well-Being Process Questionnaire. Journal of Clinical and Translational Research. doi: 10.18053/jctres.04.201802.001

Wismar, M., McKee, M., Ernst, K., Srivastava, D., \& Busse, R. (2013). Measurement of and target-setting for well-being: an initiative by the WHO Regional Office for Europe/Second meeting of the expert group Paris, France, 25-26 June 2012.

Yu.Y., Manku, M., \& Backman, C. L.(2018). Measuring occupational balance and its relationship to perceived stress and health. Canadian Journal of Occupational Therapy / Revue Canadienne D'Ergotherapie, 85(2), 117-127. doi: $10.1177 / 0008417417734355$

Yurcu, G., Çolakoğlu, Ü., \& Atay, H. (2015). The Effect of Organizational Citizenship Behavior on Subjective Well-Being. International Journal of Business and Social Science, 68(1), 120-130.

Zhao, H., Wayne, S. J., Glibkowski, B. C., \& Bravo, J. (2007).The impact of psychological contract breach on workrelated outcomes: A meta-analysis. Personnel Psychology, 60(3), 647-680. doi: 10.1111/j.17446570.2007.00087.x

Zheng, C., Molineux, J., Mirshekary, S., \& Scarparo, S. (2015). Developing individual and organisational work-life balance strategies to improve employee health and wellbeing. Employee Relations, 37(3), 354-379. doi: 10.1108/er-102013-0142 